\title{
Fraser Island Archaeological Project (FIAP): Background, Aims and Preliminary Results of Excavations at Waddy Point 1 Rockshelter
}

\author{
Ian J. McNiven ${ }^{1}$, Ian Thomas ${ }^{2}$ and Ugo Zoppi ${ }^{3}$ \\ School of Fine Arts, Classical Studies and Archaeology, University of Melbourne, Victoria, 3010, Australia \\ School of Anthropology, Geography and Environmental Studies, University of Melbourne, Victoria, 3010, Australia \\ Australian Nuclear Science and Technology Organisation, PMB 1, Menai, New South Wales, 2234, Australia
}

\begin{abstract}
Coastal southeast Queensland is one of the most intensively studied archaeological regions of Australia. While the Fraser Island World Heritage Area is the most famous landscape in this coastal region, no archaeological excavations have been undertaken and its ancient Aboriginal past remains poorly understood. The Fraser Island Archaeological Project (FIAP) redresses this situation. Excavations at Waddy Point 1 Rockshelter (WP1) in July/August 2001 reveal a focus on local resources (shellfish, fish and tool stone) in the last c.900 years. This finding is consistent with McNiven's (1999) regionalisation model which posits marine resource intensification and the development of separate residential groups occupying the dune systems of Cooloola and Fraser Island in the last 1,000 years. Further excavation will be required to define the base of the cultural deposit of WP1, which may be early Holocene given arrival of the sea off the headland c.10,000 years ago.
\end{abstract}

\section{Introduction}

The Great Sandy Region (GSR) is a single physiographic region dominated by the large active sandmasses of Cooloola and Fraser Island. The region possesses considerable archaeological and environmental integrity due to minimal European development and protection offered by incorporation within the Great Sandy National Park and the Fraser Island World Heritage Area. As such, the historical environment (e.g. flora, fauna, landforms) along with the archaeological (e.g. shell middens, stone artefact scatters) and palaeoenvironmental (e.g. dune systems, swamps) records of the GSR are available for investigation, understanding and appreciation. Furthermore, the GSR takes in the entire coastal territory of the Butchulla (or Badtjala) people who continue to assert their sovereignty. Therefore, for both environmental and cultural reasons, the GSR represents an ideal region to preserve an intact Aboriginal cultural landscape and to investigate long-term historical developments of a major Aboriginal coastal group (including responses to European invasion of the early colonial era) and their relationships to a complex, dynamic and unique environment. Such a situation is extremely unusual on the east coast of Australia.

During the 1980s, the Great Sandy Region (Fraser Island, Great Sandy Strait and Cooloola) attracted considerable archaeological attention (Figure 1). The foci of research were Cooloola and Booral, two mainland areas to the immediate south and west of Fraser Island respectively. The Cooloola Region Archaeological Project was initiated by McNiven in 1983 and resulted in a PhD thesis (McNiven 1990a; see also McNiven 1984) and numerous publications (McNiven 1985, 1990b, 1991a, 1991b, 1991c, 1991d, 1991e, 1992a, 1992b, 1992c, 1992d, 1993a, 1993b, 1999; see also McNiven 1988). Research at Booral was also initiated by McNiven with analysis undertaken by Frankland for her BA (Hons) thesis (Frankland 1990; see also McNiven 1994c). Despite this archaeological attention, the iconic gem of the GSR Fraser Island - received only minor attention (e.g. Hiscock and McNiven 1988). This paper represents an important redirection in GSR archaeological research by introducing the Fraser Island Archaeological Project (FIAP) and preliminary results of the first fieldwork season conducted in July/August 2001.

\section{Fraser Island}

Fraser Island is the world's largest sand island with an area of $1,630 \mathrm{~km}^{2}$. It is located $180 \mathrm{~km}$ north of Brisbane and has a maximum length of $122 \mathrm{~km}$, width range of $5 \mathrm{~km}$ to $25 \mathrm{~km}$, and maximum height of $235 \mathrm{~m}$ above sea level. The island is separated from the mainland by Hervey Bay and Great Sandy Strait. The southern tip of the island is only $2 \mathrm{~km}$ from the mainland (Cooloola) while the northern end is $65 \mathrm{~km}$ east of the mainland. Annual rainfall is around $1,500 \mathrm{~mm}$, two-thirds of which falls between January and June (Final Report 1976:8). Apart from selected impacts from logging and sand mining, the island has been little modified by Europeans with only three major settlements - the villages of Eurong, Happy Valley and Orchid Beach along the east coast. Fraser Island is heavily vegetated by forest and shrublands and bordered by long surf beaches along the east coast and estuarine habitats along its west coast.

\section{Island Formation}

The island consists entirely of aeolian sand dune and beach sand deposits with one exception - the volcanic promontory complex at Indian Head, Middle Rocks and Waddy Point (Whitehouse 1968:4) (Figure 2). The trachytic lavas comprising these headlands (Grimes 1987) have been potassium-argon dated to between 30 and 37 million years ago (Carlsen and Wilson 1968:15). Basalt outcrops at Waddy Point and Middle Rocks in the form of exposed dykes. In short, the range of stone tool raw materials on Fraser Island is extremely limited and localised. Eroding sands along the coast represent exposed sections of some of the numerous dune systems which have been recognised for the island. Various attempts have been made to identify and classify each of these dune systems 
(Coaldrake 1962; Stanton 1975, 1977; Thompson 1975; Ward 1977). Along with the dune systems of Cooloola, Fraser Island's dunes represent the longest dune sequences in the world, back to at least c.730,000 TL years (TejanKella et al. 1990). Freshwater creeks occur along many sections of coastline and numerous freshwater lakes spot the landscape.

Using sea floor bathymetry and the sea level rise curve of Thom and Roy (1985), and considering Evan's (1990 cited and adapted by Hall 1999) model for the formation of Moreton Bay and associated large sandy islands (Moreton and North Stradbroke islands), a hypothetical model can be developed for the formation of Fraser Island. It is clear that when sea level was $150 \mathrm{~m}$ lower than present levels at the height of the last Ice Age (c.18,000 BP), the continental shelf was dry land and Waddy Point on Fraser Island was a rocky hill fronted by a $25 \mathrm{~km}$-wide coastal plain (see Flood 1983). Between c.18,000 and c.6,500 BP (c.21,000 and c.7,500 years ago), the sea rose to its present level, flooding the continental shelf (Thom and Roy 1985). It is likely that rising seas first reached the most easterly part of Fraser Island - the headland complex which includes Waddy Point - by approximately 10,000 years ago. By 9,000 years ago, rising seas flooded much of Hervey Bay, and northern Fraser Island was a large sandy peninsula much the same as northern Cooloola is today. Between 9,000 and 7,500 years ago, Great Sandy Strait developed and Fraser Island assumed its current insular form. Dating this separation accords with a date of $6,740 \pm 80 \mathrm{BP}$ (c.7,600 cal BP) obtained on relict beach sands at Triangle Cliffs on the northwest (east side of Hervey Bay) coast of Fraser Island (Ward and Grimes 1987, 1988; see also Beach Protection Authority 1989; Coventry 1988; Flood 1983).

\section{Vegetation}

Fraser Island exhibits a complex pattern of vegetation types oriented sub-parallel to the longitudinal axis of the island (Forestry 1985a, 1985b, 1985c). A key element is a rainforest core which is a major source of ethnohistorically-recorded Aboriginal plant foods (Devitt 1979; McNiven 1992a). This core, running along the middle third of the island, averages $5 \mathrm{~km}$-wide and commences 3-4km from the east coast. Spectacular trees include satinay (Syncarpia hillii), hoop pine (Araucaria cunninghamii), kauri pine (Agathis robusta) and the piccabeen palm (Archontophoenix cunninghamiana) (Sinclair 1990:146). It is fringed by tall eucalypt forest dominated by blackbutt (Eucalyptus pilularis). The remaining southern half of the island is mostly low to medium mixed eucalypt forest dominated by scribbly gum (Eucalyptus signata). The northern half of the island is characterised by banksia shrublands and mixed eucalypt forest dominated by scribbly gum. Paperbark (Melaleuca quinquenervia) forests and huge swamps dominated by swamp banksia (Banksia robur), weeping baeckea (Baeckea stenophylla) and bungwall (Blechnum indicum), backing various sections of the island's west and southeast coasts, represent important plant food zones (Devitt 1979). A strip of shrubland supporting banksia (Banksia integrifolia), casuarina (Casuarina equisetifolia, Casuarina littoralis) and pandanus (Pandanus tectorius) backs the east coast of the island.

\section{Animals}

The potential terrestrial animal resource base of Fraser Island is relatively poor (Barry and Campbell 1977). The number of recorded native species is 87 , being: amphibians (20), reptiles (46) and mammals (21) (Barry and Campbell 1977:147). Of these, all of the amphibians are frogs/toads, many of the reptiles are either small skinks or poisonous snakes, while over half of all mammals are either small dasyurids, bats or rodents. In contrast, a wide variety of birds is present, represented by 73 water/sea species and 72 land species (Barry and Vernon 1977). The only mediumto large-sized mammals are swamp wallaby (Wallabia bicolor), mountain brushtail possum(Trichosurus caninus), sugar glider (Petaurus sp.), pigmy glider (Acrobates pygmaeus), northern brown bandicoot (Isoodon macrourus), long-nosed bandicoot (Perameles nasuta), echidna (Tachyglossus aculeatus) and dingo (Canis lupus dingo). The few isolated observations of eastern grey kangaroo (Macropus giganteus) appear to be mainland visitors only (Barry and Campbell 1977:156). Fraser Island is host to a number of freshwater turtles, fish and crayfish (Arthington 1984; Bayly et al. 1975; The Commission 1990a:76; Georges 1982). Unfortunately, few data are available on the relative abundance or commonness of animals in different vegetation zones across the island. However, Devitt (1979:52) suggests that '[i]n terms of abundance, bushrats, bandicoots, goannas and possibly tortoises show the greatest potential as Aboriginal food sources'.

The terrestrial vertebrate resource base of the island is compensated by a rich suite of marine foods. Key fish species include sea mullet (Mugil cephalus), tailor (Pomatomus saltatrix), whiting (Sillago sp.), yellowfin bream (Acanthopagrus australis) and dart (Trachinotus russelli). Of these, mullet and tailor are the most abundant, particularly during their huge annual winter/spring spawning migrations up the southern Queensland coast. In fact, the inshore waters between Indian Head and Waddy Point are a major congregation area for tailor, being one of the most important spawning locations for the species along the Australian east coast (Morton and Healy 1992:19). It appears that Fraser Island may also be the major northern limit of tailor (Pollock 1984:27).

A variety of edible shellfish can be obtained easily within the intertidal zone. The most widely distributed and abundant of these are wongs (Donax deltoides) (also known as pipi or eugarie) which occur in large colonies within sandy sediments along the surf beaches. Sand snails (Polinices incei) are occasionally associated with wongs. Hard substrate species such as oysters can be found on mangroves on the west coast along with a wide range of other estuarine shellfish. The northeastern headlands exhibit a range of rocky platform shellfish.

\section{Aboriginal Associations}

Fraser Island is within the territorial limits of the Butchulla/Badtjala people. Historical sources, including Aboriginal oral history, make it clear that Fraser Island had a 'resident population' with a strong subsistence orientation to the sea (Devitt 1979; Foley 1994; Lauer 1977; McNiven 1999; Miller 1998). The marine subsistence focus reflected the richness of the intertidal zone and waters surrounding the island for shellfish and fish. In marked contrast, 


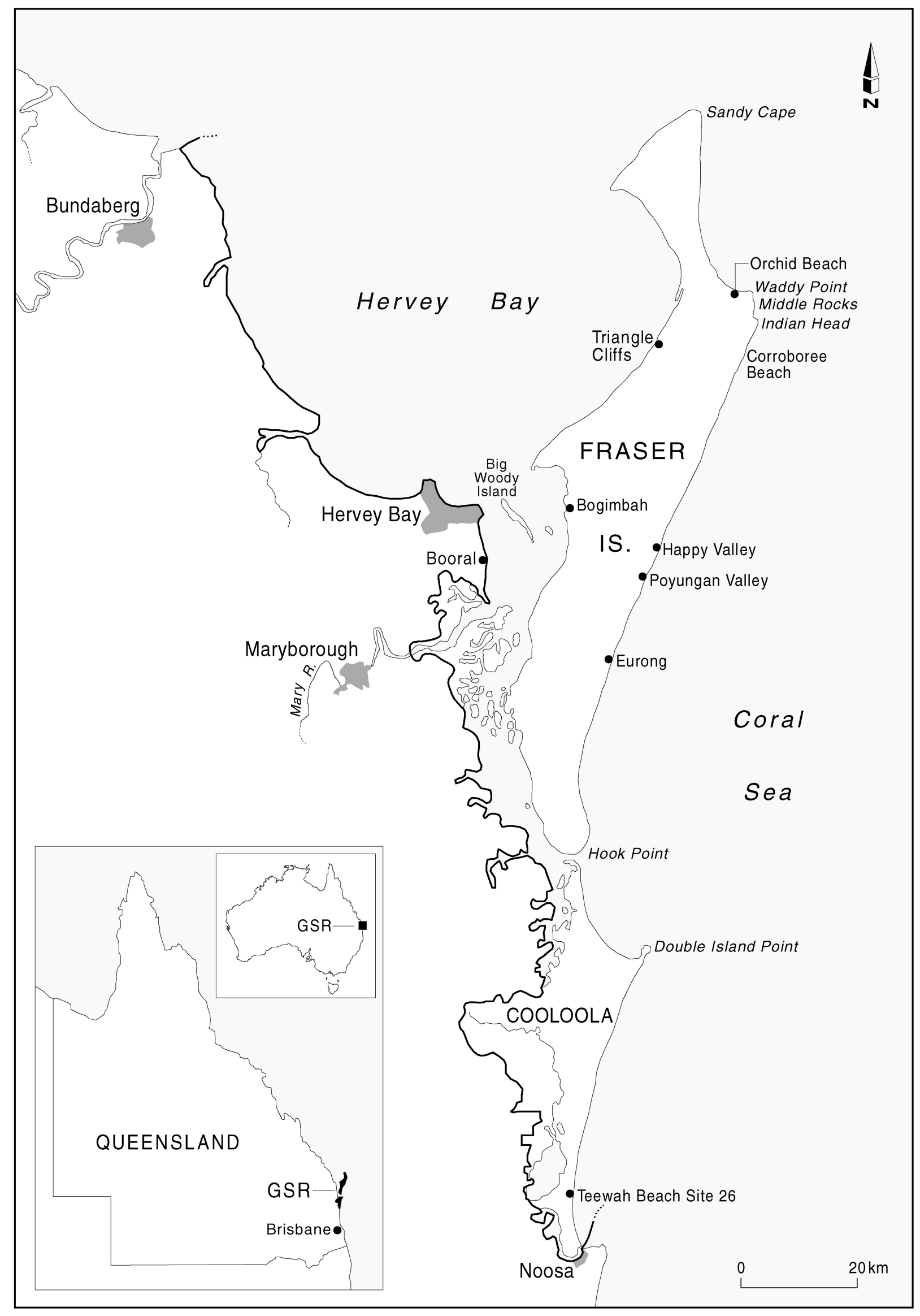

Figure 1. Study area. The Great Sandy Region is located to the east of the heavy line. 
terrestrial faunal resources of Fraser Island undoubtedly provided the required dietary variety but are too impoverished to have constituted a major economic focus for any sustained annual period. This clearly implies that the distribution and availability of land animals is not a primary consideration for any proposed settlement pattern (Devitt 1979:58).

Based on historical sources, Devitt (1979:62) proposed that fern roots (Blechnum spp.) and cycads (Cycas media and Macrozamia spp.) were 'staple' plant foods for Fraser Islanders. Both staples are concentrated across the central eastern and southeastern sections of the island, within rainforest, blackbutt forest and scribbly gum forest (Devitt 1979:71). In terms of 'potential' food resources, Devitt (1979:92) concluded that 'there was every reason for the [Aboriginal] population to be located along the island's margins and little motivation for them to be in the interior for any length of time'. Interestingly, Devitt (1979:92-93) pointed out that the southwest coast of Fraser Island along Great Sandy Strait 'provided maximum opportunities for marine exploitation'. The area was the focus of 'clan' estates on the island according to Butchulla Elder Olga Miller (1998). The overall settlement pattern was one of movement between campsites located on the east and west coasts, with relocation contingent largely upon changes in food availability (Devitt 1979; see also McNiven 1992b).

The islanders also had strong ties to the mainland (particularly Cooloola, the lower Mary River basin and Hervey Bay) which formed part of their domain. It is clear that the islanders hosted mainland visitors to share seasonal winter abundances of fish along the east coast while many islanders traveled to the mainland at certain times of the year, particularly summer when Bunya nuts ripen (Devitt 1979). This summer (inland)/winter (coast) partial transhumance was common practice in southeast Queensland(McNiven 1991c:23; Morwood 1987; Sullivan 1977). Archibald Meston estimated that the Aboriginal population of Fraser Island in the mid-nineteenth century was 2,000-3,000 (Meston 1905). Meston's estimate produces a high population density of $1.2-1.8$ people $/ \mathrm{km}^{2}$ which is slightly more than the average of around 1 person $/ \mathrm{km}^{2}$ recorded for other tropical/subtropical coastal groups in Australia (McNiven 1992c:11-12). However, in 1842, Tom Petrie observed that the 'blacks are very numerous on Frazer [sic] Island' (Petrie 1975:266). Thus, Meston's population estimate is feasible.

With colonial invasion of Australia, the world of the Fraser Islanders changed dramatically (see Evans and Walker 1977 for a detailed overview). Starting with fleeting visits by mariners in the late eighteenth and early nineteenth centuries, contact increased considerably following European pastoral settlement of the Maryborough district in the 1840 s. In the 1860 s, logging commenced on the island and the islanders found it difficult to maintain their 'traditional' lifestyle. Through a combination of disease and murder, the number of Butchulla/Badtjala living on Fraser Island was reduced dramatically in the second half of the nineteenth century. In 1897, the Queensland Government established the Bogimbah Reserve on the west coast of Fraser Island in a radical step to control, restrict and 'protect' the lives of local (and imported) Aboriginal people (Evans 1991). With its closure in 1904, many 'inmates' were transferred to other reserves in Queensland such as Yarrabah near Cairns. Other Butchulla/Badtjala stayed on in their homeland, marginalised on the fringes of the White-dominated society. In 1905, fewer than 30 Butchulla/Badtjala people lived on Fraser Island (Meston 1905).

Throughout the twentieth century, Butchulla/Badtjala people maintained a strong presence in the Maryborough/Hervey Bay/Fraser Island region (Foley 1994; McNiven 1994a). In the 1970s, members of the local Aboriginal community such as Olga Miller and Isaac Owens began voicing their concerns over the management of Fraser Island and noted that Aboriginal people never relinquished their sovereignty over the island (see McNiven 1994a for an overview). Furthermore, leaders such as Shirley Foley became increasingly involved in researching the history of the island. With the listing of Fraser Island as a World Heritage Area, Aboriginal involvement in the management of the island's rich Aboriginal heritage increased dramatically (see McNiven 1994a for an overview). Today, this involvement focusses on a series of Native Title claims over the island.

\section{Fraser Island Archaeology: Previous Views on Aboriginal Occupation}

Fraser Island witnessed two major bursts of archaeological activity with the research of Peter Lauer (1970s) and Ian McNiven (1990s) (see McNiven 1994a for a detailed overview). This research resulted in the recording and protection of hundreds of archaeological sites and a wide range of insights into past Aboriginal lifeways in the areas of settlement, subsistence, mobility, technology (mainly stone tools) and social organisation. The following section focusses on key developments in ideas concerning the antiquity of Aboriginal occupation and use of Fraser Island, with particular attention to what appear to be major periods of cultural change in the last 6,000 years. At the outset it is noted that while evidence for Aboriginal occupation in southeast Queensland extends back to at least 25,000 years ago (i.e. Wallen Wallen Creek Site, North Stradbroke Island - Neal and Stock 1986), the earliest available dates for Aboriginal sites in the GSR are at present c.5,500 years ago at Cooloola and c.1,550 years ago on Fraser Island.

\section{Lauer (1970s)}

In 1975, the Australian Government established the Fraser Island Environmental Inquiry to assess the impact of sand mining on the integrity of Fraser Island and to determine whether or not mining operations should be banned (Final Report 1976:x). Concerned about the fate of the island's Aboriginal heritage, famous novelist and Nobel laureate Patrick White provided funds for Peter Lauer, then Director of the Anthropology Museum at the University of Queensland, to undertake a reconnaissance survey of middens along the island's east coast (McNiven 1998a:38). Based on the presence of 'microliths' (backed blades) and 'core scrapers', Lauer (1975; see also 1977, 1979) speculated that Aboriginal occupation of Fraser Island may extend back to at least 5,000 years and even 30,000 years ago respectively, based on the known antiquity of these artefact types in other parts of Australia. These inferences represent the 'first archaeological reference to the potential antiquity of Aboriginal occupation of the GSR' (McNiven 1994a:17). 


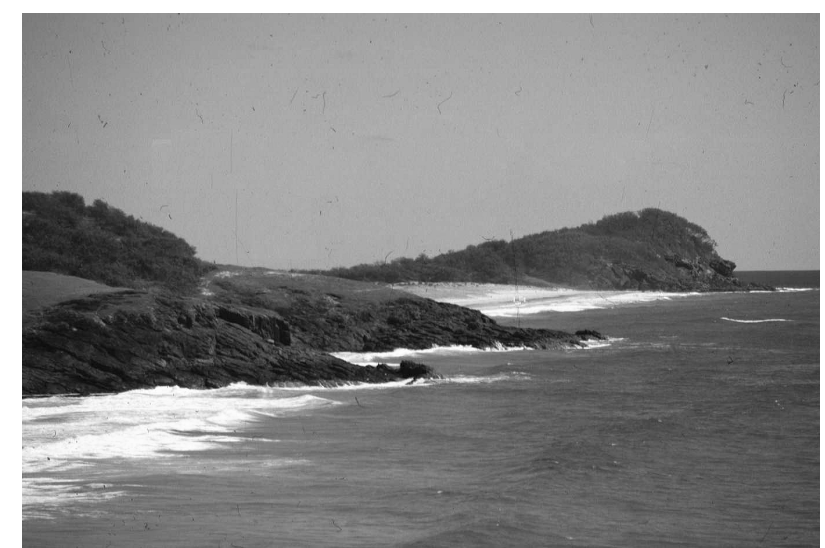

Figure 2. View from Indian Head facing north towards Middle Rocks and Waddy Point (background) (Photograph: I. McNiven).

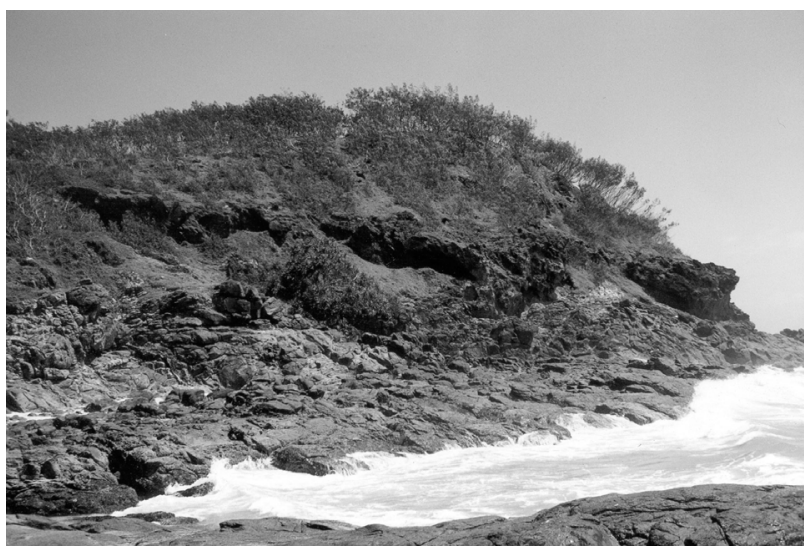

Figure 4. Trachyte escarpment featuring WP1 (far left) (Photograph: I. McNiven).

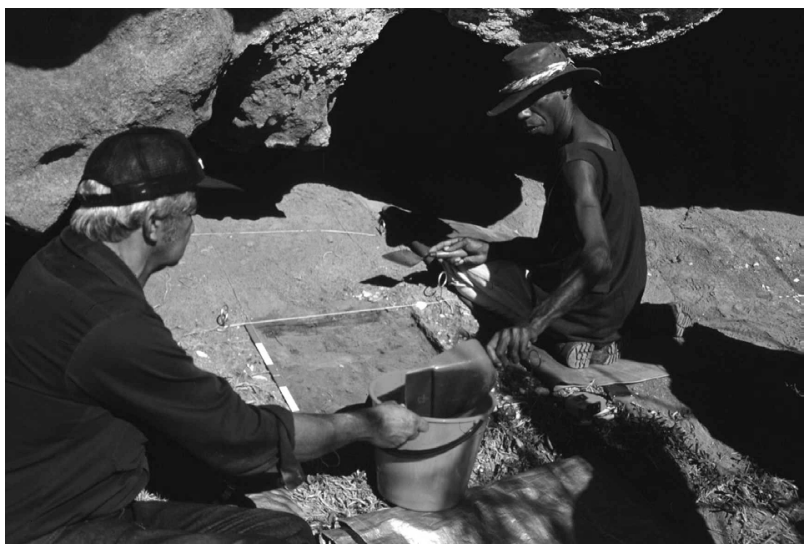

Figure 6. Excavation of WP1 by Butchulla representatives Joe Gala (right) and Fred Blackman (left) in July 2001, facing southwest (Photograph: I. McNiven).

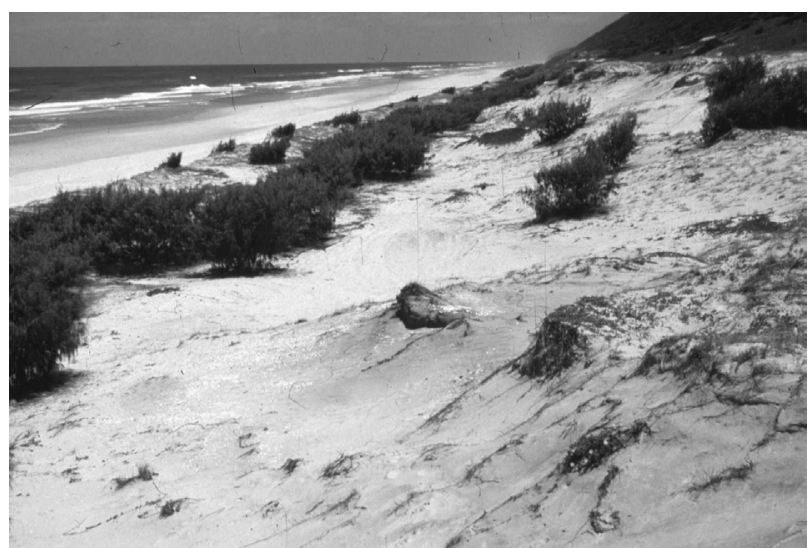

Figure 3. Eroding shell middens at the southern end of Corroboree Beach (Photograph: I. McNiven).

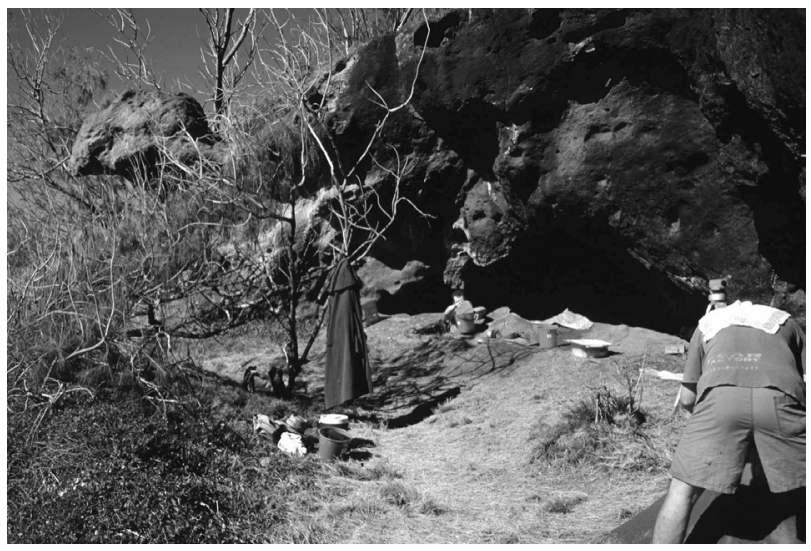

Figure 5. WP1 during excavation July 2001, facing southeast (Photograph: I. McNiven).

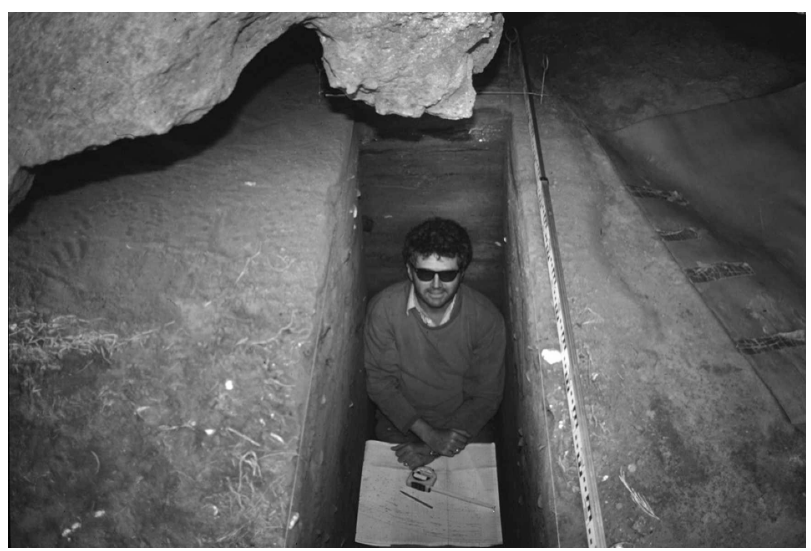

Figure 7. WP1 - Ian McNiven drawing sections in August 2001, facing south-southwest (Photograph: D. Collard). 
Table 1. Radiocarbon dates for Fraser Island shell middens obtained by Peter Lauer in the 1970s.

\begin{tabular}{|c|c|c|c|c|c|r|}
\hline Site & Lab. Code & Sample & ${ }^{14}$ C Age & $\Delta \mathbf{R}$ & Calibrated Age/ $^{\mathbf{a}}$ & Years Ago $^{\mathbf{b}}$ \\
\hline 796/54 (Corroboree Beach) & Beta-1701 & Donax deltoides & $1835 \pm 85$ & $10 \pm 7$ & $1542(1350) 1225$ & 1400 \\
\hline $796 / 54$ (Corroboree Beach) & Beta-1700 & Donax deltoides & $1965 \pm 100$ & $10 \pm 7$ & $1736(1512) 1290$ & 1550 \\
\hline $799 / 54$ (Corroboree Beach) & Beta-1699 & Donax deltoides & $1270 \pm 80$ & $10 \pm 7$ & $952(787) 652$ & 850 \\
\hline $217 / 15$ (Poyungan Valley) & Beta-1698 & Donax deltoides & $1960 \pm 110$ & $10 \pm 7$ & $1769(1509) 1276$ & 1550 \\
\hline
\end{tabular}

a Conventional radiocarbon ages were calibrated using the CALIB (v4.3) computer program (Stuiver and Reimer 1993) using the datasets of Stuiver et al. (1998) with no laboratory error multiplier. $\Delta \mathrm{R}$ recommended by Ulm (2002a, 2002b). The calibrated ages reported span the $2 \sigma$ age-range.

b Years Ago (i.e. calendar years before now - AD 2002) rounded to the nearest 50 years.

Lauer undertook major site surveys on Fraser Island in 1976 and 1977 in order to 'reconstruct lifeways of the Aboriginal population' (Lauer 1979:32). His results included the recording of 152 shell middens and 66 stone artefact scatters along the eastern sections of the island (Lauer 1977, 1979; see also Hiscock and McNiven 1988). The middens were seen as specialised shellfishing consumption sites while sandblow sites, usually located $1.5 \mathrm{~km}$ inland, were seen as complementary 'camp sites'. Devitt (1979:39) points out that the archaeological evidence concurs with nineteenth century historical records that the east coast was a major area of Aboriginal 'residence as well as exploitation' on the island.

In addition to recordings of sites and analysis of stone tools, Lauer obtained four radiocarbon dates on eroded shells from three middens along the east coast of the island (Table 1). Prior to excavations at Waddy Point 1 Rockshelter in 2001, Lauer's dates were the only radiocarbon dates available for Aboriginal sites on Fraser Island. Lauer never published the dates but details were provided by Lauer to Kelly (1982:139-141). Two dates, c. 1,400 and c. 1,550 years ago, were obtained respectively from the top and bottom of a $12 \mathrm{~cm}$-thick layer of wong shell (Site 796/54) at the southern end of Corroboree Beach located $6 \mathrm{~km}$ south of Indian Head (Figure 3 ). A single date of c. 850 years ago was obtained on surface shell (possibly deflated) over a $1 \mathrm{~m}^{2}$ area at Corroboree Beach Site 799/54. Another date of c.1,550 years ago was produced for the base of a layer of wong shell at Poyungan Valley Site $217 / 15$. Thus, the dates range over a 700 year period from 850 years ago back to 1,550 years ago.

Despite these radiocarbon dates, Lauer did not speculate on possible long-term changes in Aboriginal use of the island. Instead, he 'interpreted sites in a largely nontemporal, ahistorical framework' (McNiven 1994a:21; see McNiven 1998a for a detailed discussion of this issue). All archaeological sites were seen to simply reflect lifeways as recorded by Europeans in the late nineteenth century. In short, Fraser Island Aboriginal history was portrayed as static and unchanging - how Aboriginal people lived 200 years ago was interpreted as how they lived 1,000 s of years ago! This ahistorical perspective was subsequently reiterated (understandably) by Williams (1982) and Sinclair (1990) in their popular texts. Sinclair has even suggested occupation back to 100,000 years ago (Sinclair and Corris 1994:51).

\section{McNiven (1990s)}

The ahistorical and static perspective on Fraser Island's Aboriginal past was first challenged in the early 1990s by McNiven (1990a:385). He hypothesised that midden sites on Fraser Island may be analogous to Recent Phase (c.1,000-100 years ago) midden sites at Cooloola and sandblow sites on Fraser Island may be analogous to Early Phase (c.5,500-3,000 years ago) sandblow sites at Cooloola. McNiven (1992a:1) argued strongly for an association between sandblow sites on Cooloola and Fraser Island, using the more open Early Phase chronology of c.5,500 to 2,300 years ago reformulated by McNiven (1991c:22). It was further hypothesised that the demise of the Early Phase at Cooloola (and by extension on Fraser Island) was associated with a dramatic reduction in rainforest (a critical source of plant foods in the GSR) brought on by drier climate and burial by dune movements (McNiven 1991c:22, 1992a:11-12) and possibly changing social alliances across southeast Queensland (McNiven 1993b, 1999:162). The early occupation of the GSR at 5,500 years ago was associated with the establishment of the sea to its present level and the introduction of marine protein foods (fish and shellfish) to the region (McNiven 1991c:22). Prior to arrival of the sea, the GSR, while rich in plant food resources, was poorly suited to human occupation due to a depauperate terrestrial animal food resource base.

In December 1992, Fraser Island was inscribed on the World Heritage List and the subsequent 1993 GSR Management Plan (Fraser Implementation Unit 1993) included components of a cultural heritage management plan for the region's archaeological sites (McNiven 1992e). Implementation of the management plan included detailed site surveys by McNiven (then Cultural Heritage Officer, Great Sandy Region, Department of Environment and Heritage, Maryborough) and Butchulla/Badtjala representatives during 1993. A total of 193 sites (mostly middens) was recorded along the east coast of Fraser Island south of Waddy Point, including the extraordinary 6kmlong shell midden complex at Corroboree Beach (McNiven 1993c, 1994b, 1998b; see also McNiven and Russell 1995).

While neither excavations nor radiocarbon dates were obtained as part of this management research, two new insights were made into the antiquity of Aboriginal use of Fraser Island. First, 'European' clay pipes found on a number of shell middens at Corroboree Beach, once 
thought to be of seventeenth century Dutch origin (Sinclair 1990:68), were shown to be of English or Scottish manufacture in the mid- to late nineteenth century (McNiven 1993c:31; see Courtney and McNiven 1998 for detailed discussion). Second, backed blades (of Bondi Point form) found on a number of Corroboree Beach sites were thought to be at least 2,300 years old (and possibly c.4,000 years old) based on dated sites with similar artefacts at Cooloola and Booral (McNiven 1993c:33, 1998b:15; see also Frankland 1990; McNiven 1994c).

The most comprehensive reformulation and modeling of Fraser Island archaeology appears in McNiven (1999). It was hypothesised that despite evidence for coastal occupation in the GSR back to 5,500 years ago (i.e. Teewah Beach Site 26 at Cooloola), the first major evidence for the development of a 'specialised marine subsistence economy' is c. 3,000 years ago (i.e. Booral Shell Mound). As such, c.3,000-2,000 years may have seen the development of separate coastal (GSR) and inland (Mary River basin) peoples. More dramatic periods of marine subsistence intensification occurred within the last 1,000 years at Cooloola (i.e. Recent Phase) and possibly within the last 1,500 years on Fraser Island. This period, best exemplified by wong middens, saw 'increased residency' of the dune systems of Cooloola and Fraser Island and a dramatic increase in use of shellfish and local stone artefact raw materials. These successive phases of marine intensification are associated with a process of regionalisation whereby as a result of demographic stress (possibly linked to population increase) and consequent group fissioning, newly-formed groups established new territorial domains across the coastal dune systems of the GSR. For Fraser Island it was hypothesised that residency first occurred across the richer central third of the island (which features vital rainforest resources), and then across the relatively less productive and more marginal northern and southern sections of the island in the last 1,000 years.

Without excavation data and associated radiocarbon dates, all existing ideas on the long-term Aboriginal history of Fraser Island remain hypothetical. However, these hypotheses are far more than speculation; instead representing considered inferences that help structure the next stage of archaeological research in the region.

\section{Fraser Island Archaeological Project (FIAP) Project Aims}

The five key aims of FIAP are to:

1. Develop a research partnership with local Butchulla/Badtjala Aboriginal groups.

2. Develop a research partnership with Queensland Parks and Wildlife Service.

3. Increase broader community awareness and appreciation of Fraser Island's unique Aboriginal cultural heritage.

4. Document long-term Aboriginal use of Fraser Island, their impact on the environment through fire management, and the apparent move from itinerant use in the mid-Holocene to residential occupation and intensified marine resource use and specialisation in the late Holocene.

5. Explain these long-term developments in terms of changing social and environmental conditions.
Regarding the last two aims, an important objective will be to further test the applicability of McNiven's hypothetical regionalisation/fissioning model. This objective has broader relevance as it ties directly to a key issue in Australian coastal archaeology - understanding the relative roles of environmental and social processes in shaping the long-term development of coastal Aboriginal peoples (Hall and McNiven 1999a, 1999b:4-5). In this connection, researchers in southeast Queensland have made important contributions (e.g. Hall 1999; McNiven 1999; Morwood 1987; Walters 1989). Indeed, the archaeological record of coastal southeast Queensland represents the most intensively studied and best documented record for any coastal region in Australia. Key archaeological issues and questions which have been developed for coastal southeast Queensland and which also guide FIAP, include:

- How did Aboriginal coastal use develop in response to initial arrival of the sea (and marine resources) some 10,000-7,000 years ago and its eventual stabilisation around 4,000-3,000 years ago? While a few coastal sites are known for the period before 3,000 years ago (reviewed by Hall 1999), we still know very little about the nature of marine versus terrestrial resource use for this period due to poor preservation of food remains.

- What impact did geomorphological changes in coastline development (build-up and erosion) have on site preservation and exposure for different time periods? While research in the Moreton Region (Hall 1999) and the GSR (McNiven 1992a) has identified post-3,000 BP shoreline progradation and dune movements as key taphonomic issues respectively, more research is required to document and understand the impact of these processes on the archaeological record (Cotter 1996).

- How did Aboriginal groups respond to known climate changes, particularly the restructuring of important food resource zones such as rainforest, during the last 10,000 years? The critical issue here is the lack of palaeoenvironmental data for sub-tropical southeast Queensland and the existing and possibly inappropriate use of palaeoenvironmental models from tropical north Queensland and temperate southeast Australia (Kershaw et al. 2000; Longmore and Heijnis 1999). We urgently need a detailed program of pollen coring and palaeoenvironmental reconstruction for the late Pleistocene and Holocene of southeast Queensland.

- What environmental and social conditions set the scene for marine specialisation (i.e. the dramatic increase in shellfishing and possibly fishing) and increasing residency of the coastal lowlands ('wallum' Coaldrake 1961) in the last 3,000 years and particularly the last 1,000 years (Hall 1999; McNiven 1999; Morwood 1987; Walters 1989)? Now that it is clear that the increase in shell middens in the last 1,000 years is not a taphonomic illusion (McNiven 1991c; Ulm and Hall 1996), refinement and better testing of social explanatory models, particularly the elaborated fissioning model of McNiven (1999; see also Hall and Bowen 1989; David and Chant 1995), needs to be undertaken. 
With these local and broader issues in mind, FIAP plans a series of excavations of shell middens and sandblow stone artefact scatters across different parts of the island to obtain subsistence (mainly mollusc shells, animal bones and carbonised plants) and technological (mainly stone artefacts) materials. By documenting spatial and chronological variations in (1) the types and amounts of foods eaten, and (2) stone artefact use and manufacture (including relative use of local versus exotic raw materials), long-term changes in the use of different sections of Fraser Island by resident islanders versus mainland visitors will be determined and modeled.

The immediate focus of FIAP is previously recorded sites along the eastern sections of the island. Not only is this east coast archaeological record the best documented, its integrity is the most threatened by dune erosion and tourist visitation (currently numbering more than 250,000 people per year - The Commission 1990b:66, 77). Thus, the representativeness of sites selected for excavation can be assessed and excavation results contextualised with reference to sites located along other sections of the east coast of Fraser Island. Furthermore, significant sites being severely damaged by erosion and/or visitation can be salvaged before valuable information is lost.

In response to FIAP's aim to explore cultural change in response to environmental change, a palynological project (headed by Ian Thomas) has been established in the region. Using pollen cores taken from Holocene age swamps and lakes on Fraser Island and late Pleistocene/Holocene lake deposits on the adjacent mainland, Thomas' project will investigate long-term vegetation changes in the Great Sandy National Park and the extent to which such changes were a response to climate change and/or anthropogenic modification through Aboriginal firing.

\section{Aboriginal Partnership}

Following the close ties Lauer developed with senior members of the Butchulla/Badtala community in the 1970s and 1980s, and the inclusive approach initiated by Queensland Parks and Wildlife Service for managing Aboriginal sites on Fraser Island in the 1990s (McNiven 1994a), FIAP fully acknowledges that Fraser Island Aboriginal sites represent the cultural heritage of current generations of Butchulla/Badtjala peoples. As such, Butchulla/Badtjala people are active participants in the project. As part of the partnership process, detailed discussions were held with various senior members of the local Aboriginal community to help develop appropriate research aims and protocols. These discussions included representatives from the Korrawinga Aboriginal Corporation and the three Native Title claims on Fraser Island - Butchulla claim (particularly Marie Wilkinson), Wondunna claim (particularly Ian Desatge), and the Olga Miller claim. The partnership aims to create new insights into past Aboriginal use of Fraser Island that are in a form interesting and beneficial to the Butchulla/Badtjala community. For this to occur, the partnership is based on mutual respect where research aims do not jeopardise the integrity of scientific scholarship and Aboriginal cultural values (see McNiven and Russell in press for an extended discussion of issues concerning partnership research). It is through this partnership that FIAP aims to produce new information that enhances understanding, appreciation, protection and promotion of Fraser Island's Aboriginal archaeological and environmental heritage amongst researchers, government agencies and within the broader community.

\section{National Parks Partnership}

As Fraser Island is managed by Queensland Parks and Wildlife Service (QPWS), the protection of Aboriginal sites on the island will reflect to a large extent site protection policies developed by QPWS. As such, it is important that QPWS is actively involved with FIAP, to help maximise dissemination of research results and provide opportunities for QPWS staff to better understand the significance of Aboriginal archaeological sites on the island. At the same time, the partnership will help researchers and members of the local Aboriginal community better understand issues involved in managing and promoting Aboriginal sites on the island. In a related sense, results from Thomas' palaeoenvironmental research will provide rare insights into long-term Aboriginal management of Fraser Island's 'natural' resources, which will have direct relevance for the development of modern fire management strategies. Archaeological research will also contribute to understanding of the relative intensity of past Aboriginal use (and management) of different parts of Fraser Island.

\section{Excavation Priorities and Cultural Parameters}

A series of sites was selected for excavation along the east coast from Hook Point north to Waddy Point (Figure 1). The first fieldwork season was to focus on sites selected from Corroboree Beach. Due to concerns by various members of the Butchulla/Badtjala community that Corroboree Beach should not be disturbed due to a massacre of Aboriginal people at Indian Head in the nineteenth century, it was agreed that excavation plans would refocus on Waddy Point 1 Rockshelter located $5 \mathrm{~km}$ further to the north.

\section{Waddy Point 1 Rockshelter (WP1)}

WP1 is located at the southern end of Waddy Point within a trachyte escarpment (Figures 2, 4). It was recorded as an Aboriginal archaeological site by McNiven in 1993 (McNiven 1994b). This designation was based upon the presence of shellfish remains (e.g. wongs, thaids, nerites and hairy mussels), fish bones and charcoal eroding from what appeared to be in situ deposit. No stone artefacts were observed. The rockshelter exhibits a shallow overhang of 1-2m which expands into a $7 \mathrm{~m}$-wide by $4 \mathrm{~m}$-deep low cave (chamber) across the eastern half of the site (Figures 5, 8). This cave has a maximum roof height of $1.5 \mathrm{~m}$. The site has a northeast aspect and is located within a c.5m-high escarpment positioned approximately $20 \mathrm{~m}$ above rocky platforms and thundering surf (Figure 4). These rocky platforms can be accessed by either carefully descending the precipitous, grassy/rocky slope fronting the site or indirectly via the sandy beach to the immediate south of the headland. Relatively flat, grassy ground extends up to $5 \mathrm{~m}$ out from the site's dripline. Unlike other sections of the escarpment, considerable sediment has accumulated at WP1 because of the deeper cavernous weathering and the presence of a rock outcrop at the outer edge of the site (top of the steep slope) which traps and holds sediments before 


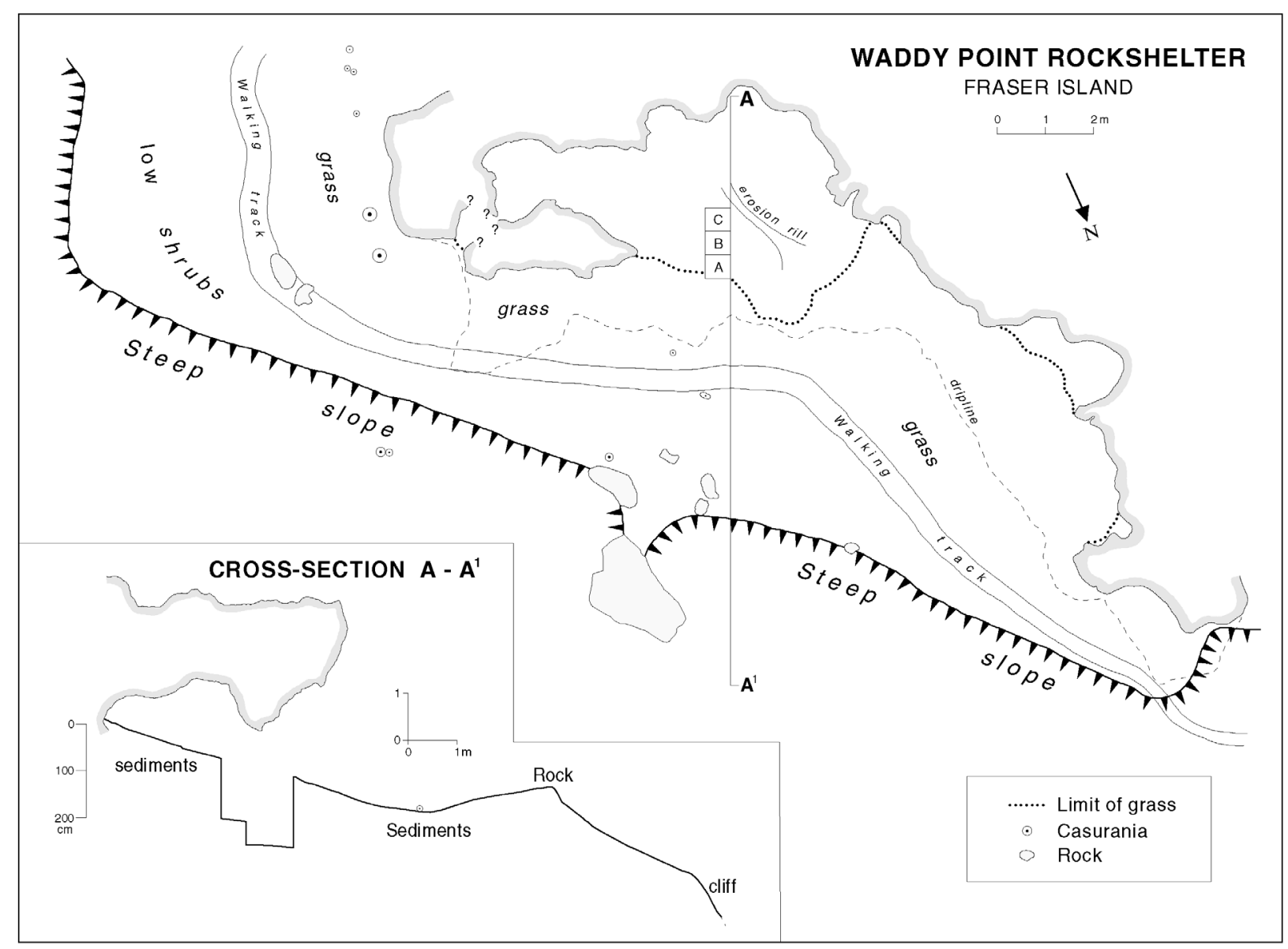

Figure 8. Waddy Point 1 Rockshelter: Site map.

they wash down the slope and into the sea. Isolated casuarina trees and shrubs extend across the outer limits of the site and back around to above the escarpment. An informal walking track runs past the site and around the base of the escarpment where cavernous weathering has created other rockshelters. While none of these shelters exhibit Aboriginal cultural materials on the surface, some exhibit sediment and thus may contain sub-surface evidence of past Aboriginal occupation.

WP1 is the only known rockshelter site in the GSR. As such it has special scientific significance given the potential of rockshelters to yield both long-term history and well preserved remains protected from the elements. WP1 was selected for excavation because understanding the long-term Aboriginal use of Fraser Island is a key aim of FIAP (see above). In particular, it was hoped that the site would yield insights into the diet and technology of Fraser Islanders before European contact. The potential for the site to exhibit a long-term coastal sequence is considerable given that the sea most likely reached Waddy Point 10,000 years ago (see above). It was predicted that the site would yield high resolution chronology as c. $10-15 \mathrm{~cm}$-deep loose sterile surface sediments within the cave suggested recent high sedimentation rates. If these sterile sediments had accumulated in the last 150 years or so, it was possible that $1 \mathrm{~m}$ of deposit could represent as much as 1,000 years of Aboriginal history. As such, WP1 provided a rare opportunity to track even small historical changes within 50-100 year periods.

\section{Excavation Methods}

WP1 was excavated over three weeks in late July and early August 2001. A $1.5 \mathrm{~m} \times 0.5 \mathrm{~m}$ trench, comprising three contiguous $50 \mathrm{~cm} \times 50 \mathrm{~cm}$ squares (Squares A, B and C), was excavated at the entrance to the cave some $80 \mathrm{~cm}$ in from the dripline and $180 \mathrm{~cm}$ from the back wall (Figure 8). This location was chosen for excavation to (1) maximise the chances of recovering well preserved remains protected from the elements, (2) avoid sterile surface sediments across the rear of the cave, (3) avoid water-affected sediments (evidenced by a small rill) at the western end of the cave (located below a roof crack), and (4) avoid steeply inclined sediments across the western sections of the cave (despite this, the surface of the trench was inclined at a moderate angle of $15^{\circ}$ ).

Excavation proceeded using arbitrary Excavation Units (XUs or spits) averaging $4 \mathrm{~cm}$ in thickness and $13.5 \mathrm{~kg}$ in weight (Figure 6). The maximum depth of the trench below the surface was $182 \mathrm{~cm}$ at the rear of Square B, followed by Square A $(164 \mathrm{~cm})$ and Square C $(134 \mathrm{~cm}$ - excluding the burrow depression). A total of $117 \mathrm{XUs}$ was removed divided as follows: Square A (39 XUs), Square B (43 XUs) and Square C (35 XUs). Detailed recordings and notes were made for each XU. The total weight of sediment excavated was $1490.3 \mathrm{~kg}$. All sediments were dry sieved through $3 \mathrm{~mm}$ mesh. Attempts to use a $1 \mathrm{~mm}$ sieve failed as sediments clogged the mesh. Sieving took place at the northern end of the site upon a plastic tarp to protect underlying sediments from contamination. Samples were 


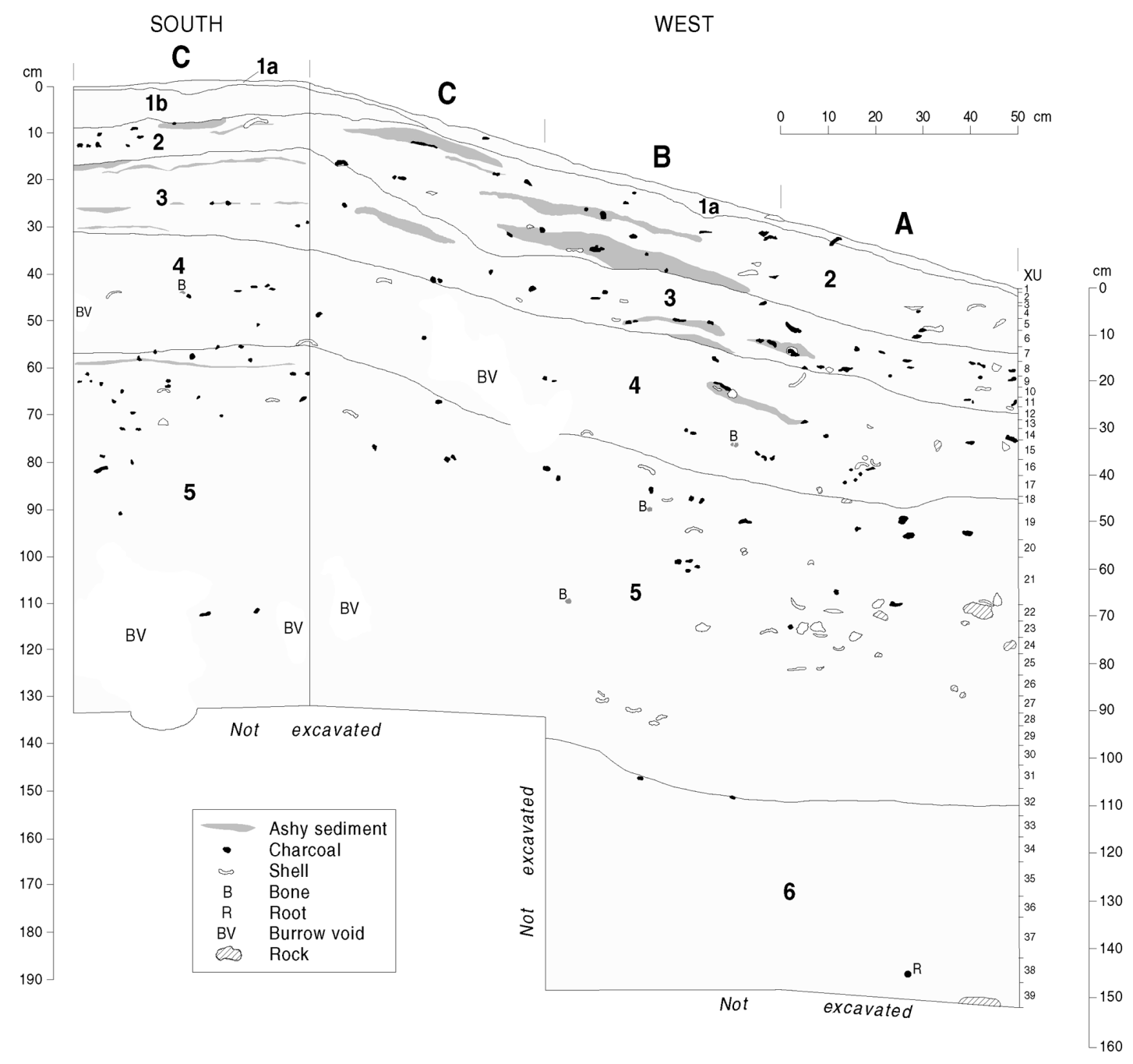

Figure 9. Waddy Point 1 Rockshelter: Stratigraphic section.

taken of sediments which passed through the $3 \mathrm{~mm}$ sieve for each XU. Sediments for each XU were tested for acidity $(\mathrm{pH})$ and colour (Munsell ${ }^{\circledR}$ Soil Color Charts). Triaxial plots were made for 69 bone, stone artefact and charcoal samples for fine resolution spatial analysis. Five elevations, measured to the nearest millimeter, were taken at the beginning and end of each XU for each square.

A number of medium- to large-sized animal burrows were exposed across the trench, mostly in Squares B and C. All burrows were easily discernable by a void or extremely loose re-fill. Re-fill by (disturbed) midden deposit was easily recognisable as it featured shells oriented vertically on their sides instead of the usual in situ horizontal aspect. Extreme care was taken to separate disturbed (burrow) cultural deposit from in situ cultural deposit. All animal burrows were emptied of re-fill upon exposure to remove the threat of this material inadvertently falling out and contaminating lower level cultural materials during excavation. Samples of re-fill were collected while the remainder was discarded and incorporated with backfill sediments. Drawings and photographic (slide) records were made of most XUs and sections (Figure 7). All sieve residues (cultural materials, roots and roof fall) were placed in plastic bags for transport back to the Archaeology
Laboratory, University of Melbourne, for analysis. The trench was backfilled first with a basal layer of white beach sand and then with fine sediments left after sieving.

\section{Cultural Deposit and Stratigraphy}

The entire deposit features cultural remains in the form of shells, bones, stone artefacts and charcoal. Based on the density of these remains, the deposit can be divided into three zones. The upper zone, taking in the top $\mathrm{c} .100 \mathrm{~cm}$ of the excavation trench, comprises a dense cultural deposit best described as a midden deposit. Beneath this 'midden' is a c.45-50cm-thick zone where the density of cultural remains decreases markedly. This zone contains the deepest unequivocal, in situ shell fragments excavated from the site (see below). The basal c. $20 \mathrm{~cm}$ of the deposit exhibits faint traces of cultural materials.

The deposit was divided into six major Stratigraphic Units (SUs) (Figure 9, Table 2). These SUs were defined on the basis of sediment colour and texture and not the presence of macro remains such as shells. Overall, the sedimentary matrix of the deposit is a reddish-brown to brown fine loamy sediment with small fragments of rock (roof fall) produced by weathering of the surrounding trachytic rock. Shell- and bone-rich deposit extends down 
Table 2. Waddy Point 1 Rockshelter: Stratigraphic Unit descriptions.

\begin{tabular}{|c|c|}
\hline SU & Description \\
\hline 1a & $\begin{array}{l}\text { Extends across the entire surface of the trench with a maximum depth of } 4 \mathrm{~cm} \text { below the surface. It comprises very loose, } \\
\text { powdery, reddish-brown }(5 \mathrm{YR}-4 / 4) \text { sediment with coarse-grained inclusions and flecks of vegetal matter (Square } \mathrm{C}) \\
\text { grading to herbaceous ground cover and rootlets (Square A). Cultural materials (shell, bone, stone artefacts and charcoal) } \\
\text { range from minor (Square } \mathrm{C} \text { ) through to considerable (Square A). The pH values are highly alkaline ( } 8.5 \text { to 9.0). }\end{array}$ \\
\hline $1 \mathrm{~b}$ & $\begin{array}{l}\text { Found only across the rear half of Square } \mathrm{C} \text { and has a maximum thickness of } 8 \mathrm{~cm} \text { and maximum depth of } 9 \mathrm{~cm} \text { below the } \\
\text { surface. It is similar to SU1a but more consolidated and without plant intrusions. }\end{array}$ \\
\hline 2 & $\begin{array}{l}\text { Extends across the entire trench with a maximum thickness of } 22 \mathrm{~cm} \text { and maximum depth of } 25 \mathrm{~cm} \text { below the surface. It } \\
\text { comprises a fine, powdery, reasonably consolidated sediment with white powdery flecks across the rear half of the trench } \\
\text { (Square C and rear half of Square B). It ranges in colour from reddish brown (5YR-4/4) to dark brown ( } 7.5 \mathrm{YR}-3 / 4) \text {. } \\
\text { Numerous lenses of ash-rich sediment occur through the SU. One of these ash-rich lenses is a hearth (fireplace) with } \\
\text { characteristic red burnt sediment underlain by dark brown burnt sediment. The SU is rich in cultural materials (shells, } \\
\text { bones, stone artefacts and charcoal). A few fibrous roots occur in Square A. The pH values range from slightly acid to } \\
\text { highly alkaline ( } 6.0 \text { to 9.0) with increasing depth. }\end{array}$ \\
\hline 3 & $\begin{array}{l}\text { Extends across the entire trench with a maximum thickness of } 21 \mathrm{~cm} \text { and maximum depth of } 36 \mathrm{~cm} \text { below the surface. It } \\
\text { comprises a fine, powdery, reasonably consolidated sediment with fine laminations across the rear sections of the trench. } \\
\text { Colour ranges from reddish brown }(5 \mathrm{YR}-4 / 4) \text { to dark brown }(7.5 \mathrm{YR}-3 / 4) \text {. Overall, sediment is slightly darker in colour than } \\
\text { SU2 and grades from a pinkish brown sediment across the rear of the trench to a reddish brown sediment across the front } \\
\text { half of the trench. White powdery flecks are found only across the upper, rear, eastern sections of the trench. As with SU2, } \\
\text { a number of ashy lenses are present and the unit is rich in cultural materials (shells, bones, stone artefacts and charcoal). } \\
\text { A few fibrous roots occur in Square A. The pH values are neutral to alkaline }(7.0 \text { to } 8.0) \text {. }\end{array}$ \\
\hline 4 & $\begin{array}{l}\text { Extends across the entire trench with a maximum thickness of } 28 \mathrm{~cm} \text { and maximum depth of } 61 \mathrm{~cm} \text { below the surface. It } \\
\text { comprises a fine, powdery, reasonably consolidated, yellowish red (5YR-4/6) sediment. It is differentiated from SU3 and } \\
\text { SU5 by its lighter and more reddish colour. A number of ashy lenses are present and the unit is rich in cultural materials } \\
\text { (shells, bones, stone artefacts and charcoal). The pH values are neutral to slightly alkaline ( } 7.0 \text { to } 7.5) \text {. }\end{array}$ \\
\hline 5 & $\begin{array}{l}\text { Extends across the entire trench with a maximum thickness of at least } 77 \mathrm{~cm} \text { and maximum depth of at least } 133 \mathrm{~cm} \text { below } \\
\text { the surface. The base of this SU was not reached in Square C. It comprises a fine, powdery, reasonably consolidated } \\
\text { sediment with fine ashy laminations across the rear of the trench in Square C. Colour grades from dark brown }(7.5 \mathrm{YR}-3 / 3) \\
\text { to brown }(7.5 \mathrm{YR}-4 / 4) \text { with depth. SU5 is differentiated from SU } 4 \text { by its darker colour and higher fraction of coarse-grained } \\
\text { inclusions. Thick ashy lenses, as seen for previous SUs, are not a feature of this unit. The top half of the unit is rich in } \\
\text { cultural materials (shells, bones, stone artefacts and charcoal). The pH values are slightly acidic to slightly alkaline }(6.5 \\
\text { to } 7.5) \text {. }\end{array}$ \\
\hline 6 & $\begin{array}{l}\text { Exposed only across the basal sections of Squares A and B. It has a maximum thickness of at least } 53 \mathrm{~cm} \text { and maximum } \\
\text { depth of } 182 \mathrm{~cm} \text { below the surface. The base of this SU was not reached. It comprises a fine, brown ( } 7.5 \mathrm{YR}-4 / 4) \text { sediment } \\
\text { that is differentiated from SU1-5 by a less powdery, more consolidated texture and darker colour. It exhibits no fibrous } \\
\text { roots but two larger roots running across the basal sections of Square A. Stone artefacts and fragments of shell, fish bone } \\
\text { and charcoal are found scattered throughout the SU. The pH values are slightly acid to neutral }(6.5 \text { to } 7.0) \text {. }\end{array}$ \\
\hline
\end{tabular}

to about $100 \mathrm{~cm}$ while the maximum depth of unequivocal in situ shell is c. $145 \mathrm{~cm}$ below the surface (Square A). Acidity $(\mathrm{pH})$ values tended to decrease with depth from 9.0 on the surface to 6.5 at the base of the trench. SUs 1-5 were tilted downwards towards the front of the rockshelter, thus following the ground surface inclination of c. $15^{\circ}$. The first indication that sediments began to level off (i.e. become horizontal) was towards the base of SU5 in Square A. The inclination of sediments is also seen in the parallel inclination of ashy deposits and shells in the stratigraphic section (Figure 9). Clearly, the Aboriginal inhabitants of the site were camping on a moderately inclined slope.

\section{Stratigraphic Integrity and Disturbance}

Except for animal burrowing (see below), the overall stratigraphic integrity of the trench was revealed by four lines of evidence. First, the deposit exhibits obvious stratification, especially towards the rear half of the trench in Square $\mathrm{C}$ were micro-laminations occur. Second, the presence of numerous ash-rich lenses inclined at the same angle as the stratigraphic units indicates that little movement of sediments has taken place since original deposition. Third, all tabular rock fragments and essentially all larger shells (particularly wong valves) and larger animals bones were lying either flat or slightly inclined at the same angle as the stratigraphic units. Fourth, a general decay profile is evident for shells. That is, shells become increasingly weathered and chalky with depth, indicating long-term in situ weathering. Weathering was most obvious on shells found scattered through the c.45-50cm of sediment below the main midden deposit. Most of these extremely chalky and fragile shell fragments were represented by the columellar of cartruts (Thais orbita). These columellar represent the most resistant part of the shell (hence the last part to weather away) and nearly all were lying flat or on a slight incline. In short, most of these lower shells are in situ and do not represent isolated shells from the upper midden deposit which fell down burrows. The in situ status of small fragments of shell and bone in the basal sediments of the trench is equivocal. 
Table 3. Waddy Point 1 Rockshelter: Radiocarbon dates, Square A.

\begin{tabular}{|c|c|c|c|c|c|c|c|}
\hline Level & $\mathbf{X U}$ & $\begin{array}{l}\text { Depth } \\
(\mathbf{c m})^{\mathrm{a}}\end{array}$ & Lab. Code & $\begin{array}{c}\text { Charcoal } \\
\text { (g) }\end{array}$ & ${ }^{14} \mathrm{C}$ Age & Calibrated Ages $^{\text {b }}$ & $\begin{array}{c}\text { Years } \\
\text { Ago }\end{array}$ \\
\hline Top & 1 & 2.5 & Wk-10122 & 5.23 & modern & modern & 150 \\
\hline Middle of midden & 17 & 54 & Wk-10123 & 3.75 & $4369 \pm 79$ & $5280(4870) 4660$ & 4900 \\
\hline Base of midden & 26 & 98.5 & Wk-10004 & 5.42 & $939 \pm 58$ & $950(880,870,830,810,790) 700$ & 900 \\
\hline Base of shell & 36 & 145 & OZF-556 & 0.29 & $1050 \pm 40$ & $1050(950,930) 800$ & 1000 \\
\hline
\end{tabular}

a Maximum depth of XU below the surface rounded to the nearest $0.5 \mathrm{~cm}$.

b Conventional radiocarbon ages were calibrated using the CALIB (v4.3) computer program (Stuiver and Reimer 1993) using the datasets of Stuiver et al. (1998) with no laboratory error multiplier. Twenty-four years were subtracted before calibration to correct for ${ }^{14} \mathrm{C}$ variation between northern and southern hemispheres. The calibrated ages reported span the $2 \sigma$ age-range. Calibrated ages reported as 'modern' are too young for the use of the calibration curve (see text).

c Years Ago (i.e. calendar years before now - AD 2002) rounded to the nearest 50 years.

The only major disturbance observed at the site was animal burrowing. These burrows were recorded in the same levels of Square A (XU3 to XU9) and Square B (XU3 to XU13) located between $4 \mathrm{~cm}$ and $27 \mathrm{~cm}$ below the surface (measured at the interface of both squares). However, section cleaning revealed an extension of the large burrow void in Square C (SU4) into Square B at a depth of $55-65 \mathrm{~cm}$ below the surface (see Figure 9). This fortuitous discovery reveals burrow disturbance in Square $\mathrm{B}$ deeper than that revealed during excavation.

Animal burrows were recorded in all levels of Square $\mathrm{C}$ (XU3 to XU35) located between $2 \mathrm{~cm}$ and $134 \mathrm{~cm}$ below the surface. Thus, while $98 \%$ of all levels of Square $C$ were disturbed by burrows, such disturbance was restricted to the top $20 \%$ of deposit in Squares A and B. The maximum width of burrows increased markedly towards the rear of the trench from $15 \mathrm{~cm}$ (Square A) to $30 \mathrm{~cm}$ (Square C). Most burrows were c.5cm-wide, indicating creation by small animals, most likely rodents. Some of the large burrows in Square $C$ represented nests padded with fine vegetal matter. It is clear that burrow disturbance increases dramatically moving from Square A (outside of the cave) to Square C (inside of the cave). This pattern suggests that burrowing is most common in cool, dry sediments within the cave which are protected from direct heat of the sun and moisture from rain blown in beyond the dripline. In terms of overall disturbance, it is concluded that Square A exhibits good integrity, Square B moderate to good integrity and Square C poor integrity. However, all sediments not affected by burrowing exhibit good integrity.

\section{Radiocarbon Dating and Chronology}

Four radiocarbon age estimates have been obtained; all from Square A (the focus of analysis to date - see below) (Table 3). The base of the midden, marking where the density of shell increases significantly, produced a date of c. 900 years ago. The top of the midden produced a date of 'modern' which suggests the site stopped being used in the nineteenth century (notionally put at AD 1850) given the absence of 'contact' materials. Thus, the midden spans approximately 750 years of Badtjala/Butchulla history.

For the level with the last unequivocal in situ shell fragments, an AMS date of c.1,000 years ago was measured at the ANTARES AMS facility at ANSTO
(Lawson et al. 2000). XU36 contained two cartrut shell columellar and a large piece of charcoal lying relatively flat in close proximity to each other within consolidated and undisturbed sediments. The date was obtained on this charcoal fragment. While a stone artefact (trachyte flake) at the base of the excavation (Square A, XU39) implies earlier activity at the site, the first evidence for unequivocal shellfishing at the site is c. 1,000 years ago.

An anomalous date of 4,369 $\pm 79 \mathrm{BP}$ was obtained for XU17 located halfway down the midden sequence where the density of cultural materials decreases considerably (see Figure 10). Assuming a reasonably constant deposition rate through the midden, XU17 should date to around 500 years ago. The fact that a radiocarbon date an order of magnitude greater was obtained for XU17 reveals that the charcoal sample submitted for age determination was contaminated with old charcoal. This intrusive charcoal may have washed into the rockshelter through the roof crack or been burrowed up by rodents from deeper sediments below the base of the excavation. While no burrows were recorded in XU17, such disturbance should not be ruled out given that burrow disturbance was revealed in Square B at this level. As this date most likely represents an 'averaged' date on numerous charcoal fragments, it is likely the sample contained charcoal fragments dating to around 500 years ago and in excess of 5,000 years ago.

\section{Laboratory Analysis}

Processing excavated materials first involved the gentle resieving of all materials through $3 \mathrm{~mm}$ mesh with freshwater. Re-sieving was necessary as dry sieving in the field was limited to avoid damage to fragile fish bones. As such, considerable soil remained after dry sieving. Once the resieved and cleaned materials had been air dried, sorting into various categories (e.g. marine shell, bone, charcoal, land snail, stone artefacts, roof fall, and natural plant matter such as roots) was undertaken using tweezers. Freshwater cleaning also included the 3D-plotted specimens, except for the charcoal samples which were simply cleaned by removing sediment with tweezers. All sorted materials were placed into sealed plastic bags for safe storage. To date, preliminary analysis results are available only for Square A (the least disturbed of the three squares). 


\section{Cultural Materials}

The range of Aboriginal cultural material recovered from WP1 includes charcoal, shells, bones, flaked stone artefacts, a bone tool and ochre (see Appendix A). Pieces of plastic, wire and human hair found in SU1 (Square C) attest to recent visitation to the site.

\section{Stone Artefacts}

Very few artefacts and no formal implement types were observed during excavation. Only 22 stone artefacts weighing 17.2g were recovered from Square A (Table 4). Raw materials are mostly local trachyte, volcanics (other) and ferruginous sandstone with two artefacts made from chert and silcrete which is not available on the island. Most artefacts $(n=11)$ were small fragments of ferruginous sandstone which forms in local sand dunes. These artefacts were designated manuports as none show signs of modification except that all must have been carried to the site from other parts of the island. Flaked ferruginous implements in the form of discoidal cores (possibly used as chopping implements) and ferruginous sandstone outcrops have been recorded nearby at Corroboree Beach (McNiven 1998 b). Most ( $n=9)$ other artefacts in Square A are flakes of trachyte and volcanic (other). These artefacts are extremely difficult to distinguish from natural roof spalls due to the coarse nature of the raw material and its associated poor flaking qualities. It is noted that none of the trachyte and volcanic (other) artefacts are identifiable unambiguously as artefacts. However, three unambiguous trachyte flakes were recorded from Square B (XUs 29, 30, 33). Raw materials for the reddish-brown trachyte flakes and grey volcanic (other) flakes are available locally at Waddy Point. This inference accords with a stone tool quarry at Waddy Point, the only known Aboriginal quarry on Fraser Island (McNiven 1994b). In marked contrast, the two exotic flakes of tan chert and grey silcrete must have been brought to Fraser Island from the mainland. The extremely small size of both these exotic artefacts of high quality raw material suggests that they represent the product of careful curation of highly valued tools (see McNiven 1992d, 1993a).

\section{Bone Point}

A bone tool in the form of a small point was recovered from XU26 (Square B) with a maximum depth of $92 \mathrm{~cm}$ below the surface in the lower levels of the midden. It has a maximum length of $53 \mathrm{~mm}$ and maximum width of $7 \mathrm{~mm}$. One end features a well-formed, polished point while the opposite end exhibits a snap fracture. The raw material for the artefact is a solid section of limb bone, probably a wallaby fibula (lower leg bone). It is likely the point dates between 500 and 900 years ago. This artefact is extremely rare, being the first bone point recovered from an archaeological site in the GSR and one of the only bone points recovered from a midden in southern Queensland. The nearest archaeological example comes from Brooyar Rockshelter near Gympie where a bone bi-point was dated to c.2,800 years ago (McNiven 1988).

No historical records document polished bone point use by Fraser Islanders. The only exception is a spear with three prongs, each tipped and barbed with a short splinter of bone, housed in the Queensland Museum (Devitt 1980; R. Robins, Queensland Museum, pers. comm., 2001). The
'Fraser Island' spear was collected in 1898 by Archibald Meston who noted that its traditional name was Geeammon kanai and that it was used to hunt flying foxes. However, doubt surrounds the origin of the spear as it probably came from the Bogimbah Mission which held Aboriginal people from many parts of Queensland (Devitt 1980). This said, Mathew (1910:120) recorded that Kabi Kabi people of the Mary River region used 'bone awls' to sew animal skins together to make 'rugs'. As the territory of the Butchulla/Badtjala people included parts of the Mary River basin, nineteenth century Fraser Islanders would have known about and probably used bone points. Use-wear and residue analysis should help identify the function of the WP1 bone point.

\section{Food Remains}

Animal food remains include shellfish, fish, crab, mammal and bird. The two most obvious shellfish within the site are cartrut shells (Thais orbita) and wongs (Donax deltoides). Other edible shellfish include sand snails (Polinices incei), nerites (Nerita sp.), hairy mussels (Trichomya hirsuta), rock oysters (Saccostrea glomerata) and limpets (Cellana sp.). Wongs and sand snails are available from the sandy surf beaches to the immediate north and south of Waddy Point; all other shellfish require rock platforms such as those found at Waddy Point headland. Thus, all of the shellfish and crab within the diet could have been collected within $1 \mathrm{~km}$ of the site.

Bones recovered from the site indicate that the diet also comprised a considerable amount of fish supplemented from time to time by birds and very occasionally by mammals. Of the few larger mammal bones observed, the only positive identification to date is a mandible of a northern brown bandicoot (Isoodon macrourus) recovered from XU8 (Square A) at a depth of $26 \mathrm{~cm}$ below the surface. This finding is significant given that bandicoots were predicted by Devitt (1979:52) to have been one of the few viable sources of terrestrial animal food for Fraser Islanders. The focus of protein needs upon marine shellfish and fish not only matches up with nineteenth century historical records, but also matches predictions based upon the poor standing of the dune country of Fraser Island and Cooloola for hunters (Devitt 1979; McNiven 1991c).

Considerable variations were documented in the relative consumption of shellfish and fish at WP1 over the last 1,000 years. Figure 10 shows two major pulses of shellfish consumption at the site. The lower pulse peaks in XU23 and the upper pulse peaks in XU12. No evidence is available to suggest these patterns simply reflect vertical changes in shell preservation. However, the decrease in shell and charcoal in the upper parts of the midden in Square A reflects in part removal of burrow fill from XU3 to XU9 during excavation. Significantly, vertical changes in charcoal also reveal two pulses of activity - one corresponding to the lower shell pulse and the other occurring well above the upper shell pulse, peaking in XU7. It is difficult to explain these changes in shellfish consumption and discard without broader knowledge on shellfish consumption patterns across other parts of the island. The changes may be idiosyncratic and specific to WP1 or part of a broader pattern of changing intensity of Aboriginal use of the island's shellfish resources during the last 1,000 years. 


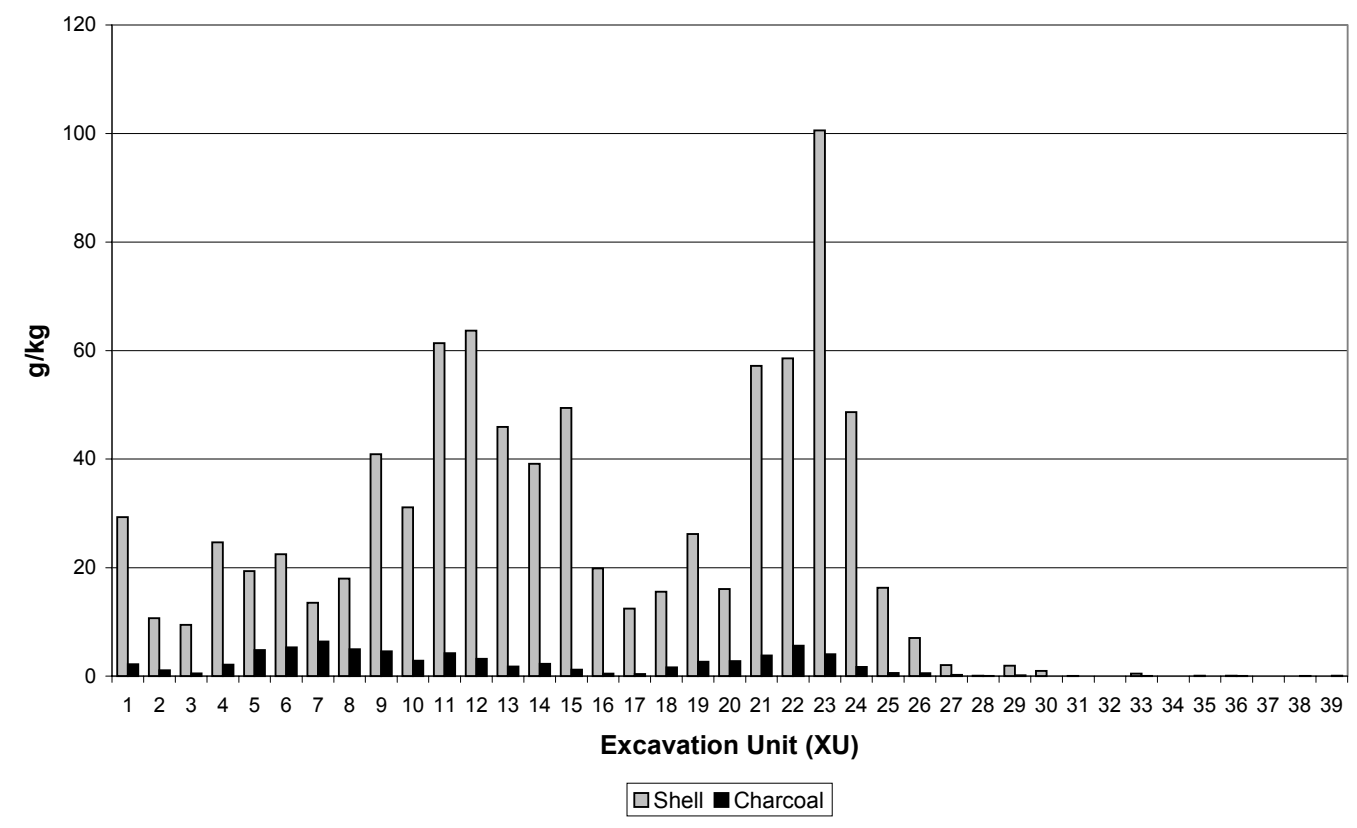

Figure 10. Waddy Point 1 Rockshelter: Vertical changes in the density of shell and charcoal (Square A).

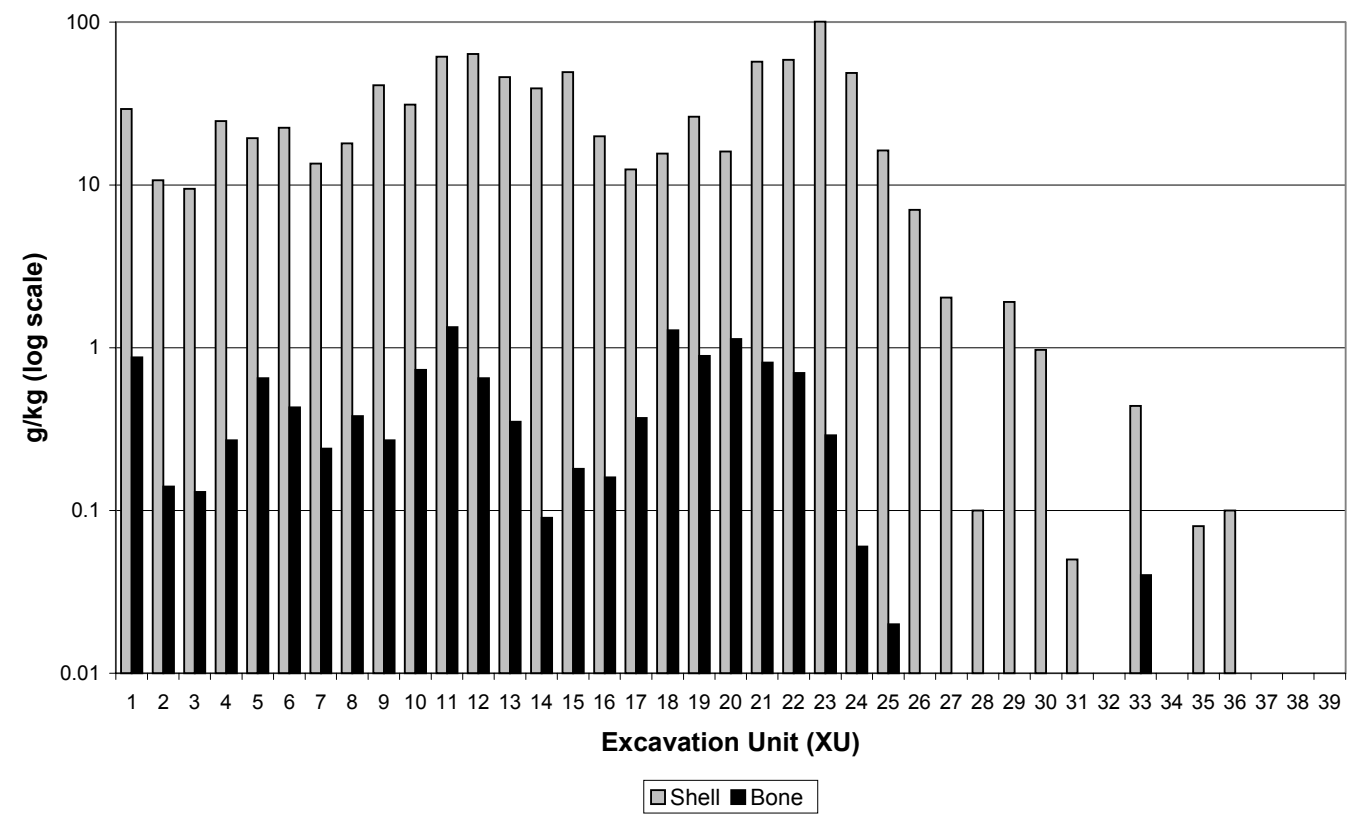

Figure 11. Waddy Point 1 Rockshelter: Vertical changes in the density of shell and bone (Square A).

Table 4. Stone artefacts from WP1, Square A. Note that weights of $0.1 \mathrm{~g}$ designate weights of $0.1 \mathrm{~g}$ or less.

\begin{tabular}{|l|c|r|r|l|}
\hline \multicolumn{1}{|c|}{ Raw Material } & Artefact Type & Number & Weight (g) & XUs \\
\hline Trachyte & flakes & 7 & 6.4 & $8,22,25,39$ \\
\hline Volcanic (Other) & flakes & 2 & 0.2 & 9,15 \\
\hline Chert & flake & 1 & 0.1 & 31 \\
\hline Silcrete & flake & 1 & 0.1 & 6 \\
\hline Ferruginous Sandstone & manuports & 11 & 10.4 & $6,7,21$ \\
\hline TOTAL & - & 22 & 17.2 & - \\
\hline
\end{tabular}


Vertical changes in the density of bone also track vertical changes in shell density (Figure 11). Bone, which is mostly fish bone, only becomes a consistent part of the faunal assemblage after the commencement of the main midden deposit in XU26. That is, bone only features in the site once the density of shell reaches more than $9-10 \mathrm{~g} / \mathrm{kg}$ of deposit. Two, not necessarily mutually exclusive, hypotheses may account for this pattern of bone occurrence. First, the ratio of fish to shellfish in the diet remains relatively constant through time. Thus, as the quantity of shells increases in a level, so too will the quantity of fish bone (and vice versa). Second, as fish bone needs to be surrounded by shell to preserve in the alkaline to acid sediments of southeast Queensland, the density of fish bone in different levels of a site will simply reflect the density of shell in corresponding levels of the site (McNiven 1991c:21). At present no simple methodology exists to clearly differentiate between these two alternative hypotheses. Further taphonomic analysis of fish bones at WP1, including chemical analysis of sediment samples and examination of possible correlations between shell density and preservational quality of individual bones (e.g. degree of acid etching, size of fragments etc), may help resolve the issue.

\section{Ochre}

A number of tiny fragments of red ochre $(0.02 \mathrm{~g})$ was recovered from XU20 in Square A. This material is freely available along the east coast of Fraser Island amongst what is locally referred to as the 'coloured sands'. Clearly, red ochre use at the site was extremely rare. The recovered ochre may have been used as body decoration (e.g. Curtis 1838:62) and/or to paint artefacts.

\section{Discussion and Conclusion \\ Cultural Changes c.900 Years Ago in the GSR}

Available dates indicate that something rather dramatic occurred in the use of WP1 c.900 years ago. Such changes are represented by a major increase in shellfishing (and possibly fishing) to the point that a midden deposit formed in the rockshelter, eventually raising the floor level by $1 \mathrm{~m}$. This timing can also be tied to synchronous changes in the GSR. For example, the earliest midden excavated at Cooloola dates to c.900-1,000 years ago (Teewah Beach 26 - McNiven 1991c; Ulm and Reid 2000:33) while the Booral Shell Mound stopped being used c.900 years ago (Frankland 1990; Ulm and Reid 2000:18) and the most recent date obtained by Lauer for middens on the east coast of Fraser Island was c.850 years ago (Table 1).

The WP1 findings are significant for they provide the first empirical support for McNiven's (1999) hypothesis that increases in Aboriginal use of Cooloola during the last c. 900 years also took place on neighbouring Fraser Island (see also Ulm and Hall 1996). This increase in activity was associated with the establishment of residential groups across Cooloola and Fraser Island, which saw more permanent occupation of the dune systems and coast, and intensified use of local resources such as shellfish, fish and headland stone for tool manufacture. Indeed, the almost exclusive use of local (headland) volcanic stone at WP1 highlights the fact that this site represents a local Butchulla/Badtjala site and not a site used by visitors (bearing exotic stone) to the island. It also highlights exotic (mainland) stone use at many midden sites along
Corroboree Beach $5 \mathrm{~km}$ to the south, and complements the view that Corroboree Beach was one place where Fraser Islanders hosted visitors to feast on super abundances of fish in winter (McNiven 1998b).

\section{Deeper and Older Cultural Materials at WP1?}

The presence of a stone artefact at the base of the WP1 excavation (Square A, XU39) suggests strongly that the base of the cultural deposit at the site has not been reached. As such, plans are being made for a second phase of excavation at the site to sample older cultural materials and establish when Aboriginal people first began using the site. It is predicted that occupation of WP1 extends back to the early Holocene given that the sea reached Waddy Point c. 10,000 years ago. The possibility that the intrusive c.5,000 year old plus charcoal in Square A, XU17 came from deeper sediments below the base of the excavation pit also hints at the potential of the site to contain much older cultural materials.

While WP1 exhibits potential to yield insights into the long-term Aboriginal history of Fraser Island, its representativeness for land-use patterns across other parts of this environmentally diverse island is questionable. Clearly, excavation and analysis of WP1 must be carried out in conjunction with excavation of a range of sites from different parts of Fraser Island. Apart from new insights into Aboriginal use of Fraser Island, excavation results will provide a broader chronological framework to contextualise and understand the significance of Lauer's pioneering research, particularly his dated midden sites.

\section{Acknowledgements}

Primary thanks is extended to the Butchulla/Badtjala community for allowing this project to unfold and in particular Narelle Blackman, Joyce Bonner, Ian Desatge, Frances Gala, Susan Hansen, Olga Miller and Marie Wilkinson. Special thanks to Marie Wilkinson for behind-the-scenes organisation, assistance and guidance. Fieldwork was made possible by the efforts and good humour of Fred Blackman, Eddie Doolan, Kate Doolan, Joe Gala, Peter Martin and Nathan Mason. Field assistance and good company was also provided by Jeremy Ash and Dave Collard (University of Melbourne). The Queensland Parks and Wildlife Service (Great Sandy National Park) provided much needed support during fieldwork and issued a research permit. Thanks to Lachie Fullerton (Manager, Great Sandy) and Glenn Comerford, Dan Eckert, Paul Fishburn, John Ford, Eric Glassop, Michelle Grimes, Col Lawton, Joanne Marland, Cheryl Page, John Schwarzrock, Aubrey Strydom and Steve Winderlich. Rob Neal (Queensland Environmental Protection Agency) kindly assisted with the issuing of an excavation permit and showed keen interest in management of midden sites during a visit to the island in May 2001. Richard Robins (Queensland Museum) provided valuable information on Fraser Island Aboriginal spears. Thanks to the Orchid Beach Trading Post and Bill and Helen Bennett for logistical support and hospitality. Figures were prepared by Chandra Jayasuriya (School of Anthropology, Geography and Environmental Studies, University of Melbourne). Finally, this project was made possible by funds provided by a Melbourne Research Development Grant (University of Melbourne) and UniMArch Consulting (University of Melbourne).

\section{References Cited}

Arthington, A.H. 1984 Freshwater fish of North Stradbroke, Moreton and Fraser Islands. In R.J. Coleman, J. Covacevich and P. Davie (eds), Focus on Stradbroke: New Information on North Stradbroke Island and Surrounding Areas, 19741984, pp.279-282. Brisbane: Boolarong Publications. 
Barry, D.H. and P.R. Campbell 1977 A survey of the mammals and herptiles of Fraser Island, with comments on the Cooloola peninsula, North Stradbroke, Moreton and Bribie Islands. University of Queensland, Anthropology Museum, Occasional Papers in Anthropology 8:147-177.

Barry, D.H. and D.P. Vernon 1977 The birds of Fraser Island, with comments on the Cooloola peninsula, Stradbroke, Moreton and Bribie Islands. University of Queensland, Anthropology Museum, Occasional Papers in Anthropology 8:179-205.

Bayly, A., E.P. Ebsworth and H.F. Wan 1975 Studies on the lakes of Fraser Island, Queensland. Australian Journal of Marine and Freshwater Research 26:1-13.

Beach Protection Authority 1989 Hervey Bay Beaches: A Detailed Study of Coastline Behaviour Along the Mainland Beaches of Hervey Bay, South-East Queensland, Australia. Brisbane: Government Printer.

Carlsen, C.T. and T.C. Wilson 1968 Gulf - A.O.G. Capricorn No. 1A Well Completion Report. Australian Gulf Oil Company. Unpublished report CR2408, Department of Minerals and Energy, Brisbane.

Coaldrake, J.E. 1961 The Ecosystem of the Coastal Lowlands ('Wallum') of Southern Queensland. CSIRO Bulletin 283. Melbourne: Commonwealth Scientific and Industrial Research Organisation.

Coaldrake, J.E. 1962 The coastal sand dunes of southern Queensland. Proceedings of the Royal Society of Queensland 72(7):101-116.

Cotter, M. 1996 Holocene environmental change in Deception Bay, southeast Queensland: A palaeogeographical contribution to MRAP Stage II. In S. Ulm, I. Lilley and A. Ross (eds), Australian Archaeology '95: Proceedings of the 1995 Australian Archaeological Association Annual Conference, pp.193-205. Tempus 6. St Lucia: Anthropology Museum, University of Queensland.

Courtney, K. and I.J. McNiven 1998 Clay tobacco pipes from Aboriginal middens on Fraser Island, Queensland. Australian Archaeology 47:44-53.

Coventry, R.J. 1988 Discussion: History of coastal dunes at Triangle Cliff, Fraser Island, Queensland. Australian Journal of Earth Science 35:579-583.

Curtis, J. 1838. The Shipwreck of the Stirling Castle. London: George Virtue.

David, B. and D. Chant 1995 Rock art and regionalisation in north Queensland prehistory. Memoirs of the Queensland Museum 37(2):357-528.

Devitt, J. 1979 Fraser Island: Aboriginal Resources and Settlement Pattern. Unpublished BA (Hons) thesis, Department of Anthropology and Sociology, University of Queensland, Brisbane.

Devitt, J. 1980 Fraser Island material culture. University of Queensland, Anthropology Museum, Occasional Papers in Anthropology 10:9-22.

Evans, K. 1990 Quaternary Stratigraphy of the Brisbane River Delta. Unpublished BAppSc (Hons) thesis, Department of Applied Geology, Queensland University of Technology, Brisbane.

Evans, R. 1991 'A Permanent Precedent': Dispossession, Social Control and the Fraser Island Reserve and Mission, 18971904. Ngulaig 5. Brisbane: Aboriginal and Torres Strait Islander Studies Unit, University of Queensland.

Evans, R. and J. Walker 1977 "These strangers, where are they going?": Aboriginal-European relations in the Fraser Island and Wide Bay region 1770-1905. University of Queensland, Anthropology Museum, Occasional Papers in Anthropology 8:39-105.
Final Report 1976 Australian Fraser Island Environmental Inquiry - Final Report. Canberra: Australian Government Publishing Service.

Flood, P.G. 1983 Holocene sea level data from the southern Great Barrier Reef and southeastern Queensland - A review. In D. Hopley (ed.), Australian Sea Levels in the Last 15000 Years: A Review, pp.85-92. Occasional Paper 3. Townsville: Department of Geography, James Cook University.

Foley, S. 1994 The Badtjala People. Hervey Bay: Thoorgine Educational and Cultural Centre Aboriginal Corporation Inc.

Forestry 1985a Fraser Island South Sheet, 1:50,000 vegetation map, edition 2. Brisbane: Department of Forestry.

Forestry 1985b Fraser Island Central Sheet, 1:50,000 vegetation map, edition 2. Brisbane: Department of Forestry.

Forestry 1985c Fraser Island North Sheet, 1:50,000 vegetation map, edition 2. Brisbane: Department of Forestry.

Frankland, K. 1990 Booral: Preliminary Investigation of an Archaeological Site in the Great Sandy Strait Region, Southeast Queensland. Unpublished BA (Hons) thesis, Department of Anthropology and Sociology, University of Queensland, Brisbane.

Fraser Implementation Unit 1993 Great Sandy Region Management Plan (Draft). Queensland Department of Environment and Heritage, Brisbane.

Georges, A. 1982 Diet of the Australian freshwater turtle Emydura krefftii (Chelonia: Chelidae), in an unproductive lentic environment. Copeia X(2):331-336.

Grimes, K.G. 1987 The volcanic rocks of the Waddy Point Indian Head area. In C.G. Murray and J.B. Waterhouse (eds), 1987 Field Conference Gympie District, pp.54-59. Brisbane: Geological Society of Australia, Queensland Division.

Hall, J. 1999 The impact of sea level rise on the archaeological record of the Moreton region, southeast Queensland. In J. Hall and I.J. McNiven (eds), Australian Coastal Archaeology, pp.169-184. Research Papers in Archaeology and Natural History 31. Canberra: Archaeology and Natural History Publications, Department of Archaeology and Natural History, Research School of Pacific and Asian Studies, Australian National University.

Hall, J. and G. Bowen 1989 An excavation of a midden complex at the Toulkerrie Oysterman's Lease. Queensland Archaeological Research 6:3-27.

Hall, J. and I.J. McNiven (eds) 1999a Australian Coastal Archaeology. Research Papers in Archaeology and Natural History 31. Canberra: Archaeology and Natural History Publications, Department of Archaeology and Natural History, Research School of Pacific and Asian Studies, Australian National University.

Hall, J. and I.J. McNiven 1999b Australian coastal archaeology: Introduction. In J. Hall and I.J. McNiven (eds), Australian Coastal Archaeology, pp.1-5. Research Papers in Archaeology and Natural History 31. Canberra: Archaeology and Natural History Publications, Department of Archaeology and Natural History, Research School of Pacific and Asian Studies, Australian National University.

Hiscock, P. and I.J. McNiven 1988 Small unifacial pebble cores from Fraser Island, S.E. Queensland. Queensland Archaeological Research 5:161-165.

Kelly, M. 1982 A Practical Reference Source to Radiocarbon Dates Obtained from Archaeological Sites in Queensland. Cultural Resource Management Monograph Series 4. Brisbane: Department of Community Services.

Kershaw, P., P.G. Quilty, B. David, S. van Huet and A. McMinn 2000 Palaeobiogeography of the Quaternary of Australasia. Memoir of the Association of Australasian Palaeoontologists 23:471-516. 
Lauer, P.K. 1975 Ethnohistorical observations on Fraser Island. Manuscript submitted to the Fraser Island Environmental Inquiry, Exhibit No. 543. Australian Archives, Canberra, A3911 Series.

Lauer, P.K. 1977 Report on a preliminary ethnohistorical and archaeological survey of Fraser Island. University of Queensland, Anthropology Museum, Occasional Papers in Anthropology 1:1-38.

Lauer, P.K. 1979 The museum's role in fieldwork: The Fraser Island study. University of Queensland, Anthropology Museum, Occasional Papers in Anthropology 9:31-72.

Lawson, E.M., G. Elliott, J. Fallon, D. Fink, M.A.C. Hotchkis, Q. Hua, G.E. Jacobsen, P. Lee, A.M. Smith, C. Tuniz and U. Zoppi 2000 AMS at ANTARES - The first 10 years. Nuclear Instruments and Methods in Physics Research Section B: Beam Interactions with Materials and Atom 172:95-99.

Longmore, M.E. and H. Heijnis 1999 Aridity in Australia: Pleistocene records of palaeocological change from perched lake sediments of Fraser Island, Queensland, Australia. Quaternary International 57/58:35-47.

Mathew, J. 1910 Two Representative Tribes of Queensland. London: T. Fisher Unwin.

McNiven, I.J. 1984 Initiating Archaeological Research in the Cooloola Region, Southeast Queensland. Unpublished BA (Hons) thesis, Department of Anthropology and Sociology, University of Queensland, Brisbane.

McNiven, I.J. 1985 An archaeological survey of the Cooloola Region, S.E. Queensland. Queensland Archaeological Research 2:4-37.

McNiven, I.J. 1988 Brooyar Rockshelter: A late Holocene seasonal hunting camp from southeast Queensland. Queensland Archaeological Research 5:133-160.

McNiven, I.J. 1990a Prehistoric Aboriginal Settlement and Subsistence in the Cooloola Region, Coastal Southeast Queensland. Unpublished PhD thesis, Department of Anthropology and Sociology, University of Queensland, Brisbane.

McNiven, I.J. 1990b Blowout taphonomy: Non-cultural associations between faunal and stone artefact assemblages along the Cooloola coast, southeast Queensland. Australian Archaeology 31:67-74.

McNiven, I.J. 1991a The resharpening of bevel-edged tools from coastal southeast Queensland. Memoirs of the Queensland Museum 30(3):493-504.

McNiven, I.J. 1991b The Double Island Point Aboriginal burials, coastal southeast Queensland. Australian Archaeology 32:1016.

McNiven, I.J. 1991c Teewah Beach: New evidence for Holocene coastal occupation in southeast Queensland. Australian Archaeology 33:14-27.

McNiven, I.J. 1991d Settlement and subsistence activities along Tin Can Bay, southeast Queensland. Queensland Archaeological Research 8:85-107.

McNiven, I.J. 1991e Prehistoric Aboriginal Settlement and Subsistence in the Cooloola Region, Coastal Southeast Queensland ( $\mathrm{PhD}$ thesis abstract). Australian Archaeology 33:67.

McNiven, I.J. 1992a Mid-Holocene sandblow sites in the Great Sandy Region, coastal southeast Queensland: Implications for models of late Holocene rainforest exploitation and settlement restructuring. Queensland Archaeological Research 9:1-16.

McNiven, I.J. 1992b Shell middens and mobility: The use of offsite faunal remains, Queensland, Australia. Journal of Field Archaeology 19(4):495-508.
McNiven, I.J. 1992c Ethnohistorical reconstructions of Aboriginal lifeways along the Cooloola coast, southeast Queensland. Proceedings of the Royal Society of Queensland 102:5-24.

McNiven, I.J. 1992d Bevel-edged tools from coastal southeast Queensland. Antiquity 66(252):701-709.

McNiven, I.J. 1992e Cultural Heritage Management Plan - Great Sandy Region, Southeastern Queensland. Unpublished report to Department of Environment and Heritage, Brisbane.

McNiven, I.J. 1993a Raw material proximity and bevel-edged tool use, Teewah Beach, southeast Queensland. Archaeology in Oceania 28(3):138-143.

McNiven, I.J. 1993b Tula adzes and bifacial points on the east coast of Australia. Australian Archaeology 36:22-33.

McNiven, I.J. 1993c Corroboree Beach, Fraser Island: Archaeological Survey and Management Recommendations. 3 vols. Unpublished report to Department of Environment and Heritage, Maryborough.

McNiven, I.J. 1994a "Relics of a By-Gone Race"?: Managing Aboriginal Sites in the Great Sandy Region. Ngulaig 12. Brisbane: Aboriginal and Torres Strait Islander Studies Unit, University of Queensland.

McNiven, I.J. 1994b East Coast, Fraser Island (Hook Point to Waddy Point): Archaeological Survey and Management Recommendations. 3 vols. Unpublished report to Department of Environment and Heritage, Maryborough.

McNiven, I.J. 1994c Booral: Cultural Heritage Management Plan. Unpublished report to Department of Environment and Heritage, Maryborough.

McNiven, I.J. 1998a Shipwreck saga as archaeological text: Reconstructing Fraser Island's Aboriginal past. In I.J. McNiven, L. Russell and K. Schaffer (eds), Constructions of Colonialism: Perspectives on Eliza Fraser's Shipwreck, pp.37-50. London: Leicester University Press.

McNiven, I.J. 1998b Aboriginal archaeology of the Corroboree Beach dune field, Fraser Island: Re-survey and reassessment. Memoirs of the Queensland Museum, Cultural Heritage Series 1:1-22.

McNiven, I.J. 1999 Fissioning and regionalisation: The social dimensions of changes in Aboriginal use of the Great Sandy Region, coastal S.E. Queensland. In J. Hall and I.J. McNiven (eds), Australian Coastal Archaeology, pp.157-168. Research Papers in Archaeology and Natural History 31. Canberra: Archaeology and Natural History Publications, Department of Archaeology and Natural History, Research School of Pacific and Asian Studies, Australian National University.

McNiven, I.J. and L. Russell 1995 Place with a past: Reconciling wilderness and the Aboriginal past in World Heritage areas. Royal Historical Society of Queensland Journal 15:505-519.

McNiven, I.J. and L. Russell in press Towards a decolonisation of Australian indigenous archaeology. In C. Chippindale and H. Maschner (eds) Handbook of Archaeological Theory. Walnut Creek, CA: Altamira Press.

Meston, A. 1905 Report on Fraser Island. Brisbane: Queensland Legislative Assembly.

Miller, O. 1998 K'gari, Mrs Fraser and Butchulla oral tradition. In I.J. McNiven, L. Russell and K. Schaffer (eds), Constructions of Colonialism: Perspectives on Eliza Fraser's Shipwreck, pp.28-36. London: Leicester University Press.

Morton, R.M. and T. Healy 1992 Fisheries Resources of the Fraser Island Region. Brisbane: Queensland Fish Management Authority.

Morwood, M.J. 1987 The archaeology of social complexity in south-east Queensland. Proceedings of the Prehistoric Society 53:337-350. 
Neal, R. and E. Stock 1986 Pleistocene occupation in the southeast Queensland coastal region. Nature 323:618-621.

Petrie, C.C. 1975 [1904] Tom Petrie's Reminiscences of Early Queensland. Windsor: Curry O'Neil.

Pollock, B.R. 1984 The tailor (Pomatomus saltatrix) fishery at Fraser Island and its relation to the life-history of the fish. Proceedings of the Royal Society of Queensland 95:23-28.

Sinclair, J. 1990 Fraser Island and Cooloola. Sydney: Weldon.

Sinclair, J. and P. Corris 1994 Fighting for Fraser Island: A Man and an Island. Alexandria: Kerr.

Stanton, P. 1975 A Report on Fraser Island - Natural History, Land Use, Land Classification and a Proposed Framework for its Management. Manuscript submitted to the Fraser Island Environmental Inquiry, Exhibit No. 9. Australian Archives, Canberra, A3911 Series.

Stanton, P. 1977 Landscape classification on Fraser Island. University of Queensland, Anthropology Museum, Occasional Papers in Anthropology 8:127-133, 256.

Stuiver, M. and P.J. Reimer 1993 Extended ${ }^{14} \mathrm{C}$ data base and revised CALIB $3.0{ }^{14} \mathrm{C}$ age calibration program. Radiocarbon 35(1):215-230.

Stuiver, M., P.J. Reimer, E. Bard, J.W. Beck, G.S. Burr, K.A. Hughen, B. Kromer, G. McCormac, J. van der Plicht and M. Spurk 1998 INTCAL98 Radiocarbon age calibration 24,000 - 0 cal BP. Radiocarbon 40(3):1041-1083.

Sullivan, H. 1977 Aboriginal Gatherings in South-East Queensland. Unpublished BA (Hons) thesis, Australian National University, Canberra.

Tejan-Kella, M.S., D.J. Chittleborough, R.W. Fitzpatrick, C.H. Thompson, J.R. Prescott and J.T. Hutton 1990 Thermoluminescence dating of coastal sand dunes at Cooloola and North Stradbroke Island, Australia. Australian Journal of Soil Research 28:465-481.

The Commission 1990a Final Discussion Paper Volume I: Background. Commission of Inquiry into the Conservation, Management and Use of Fraser Island and the Great Sandy Region. Brisbane: Queensland Government Printer.

The Commission 1990b Final Discussion Paper Volume III: Issues. Commission of Inquiry into the Conservation, Management and Use of Fraser Island and the Great Sandy Region. Brisbane: Queensland Government Printer.
Thom, B.G. and P.S. Roy 1985 Relative sea levels and coastal sedimentation in southeast Australia in the Holocene. Journal of Sedimentary Petrology 55(2):257-264.

Thompson, C. 1975. Coastal areas of southern Queensland some land-use conflicts. Proceedings of the Royal Society of Queensland 86:109-120.

Ulm, S. 2002a Marine and estuarine reservoir effects in central Queensland, Australia: Determination of $\Delta \mathrm{R}$ values. Geoarchaeology: An International Journal 17(4):319-348.

Ulm, S. 2002b Calibrating marine radiocarbon dates: A guide to Australian $\triangle \mathrm{R}$ values. AACAI Newsletter 89:10-14.

Ulm, S. and J. Hall 1996 Radiocarbon and cultural chronologies in southeast Queensland prehistory. In S. Ulm, I. Lilley and A. Ross (eds) Australian Archaeology '95: Proceedings of the 1995 Australian Archaeological Association Annual Conference, pp.45-62. Tempus 6. St Lucia: Anthropology Museum, University of Queensland.

Ulm, S. and J. Reid 2000 Index of dates from archaeological sites in Queensland. Queensland Archaeological Research 12:1129.

Walters, I. 1989 Intensified fishery production at Moreton Bay, southeast Queensland, in the late Holocene. Antiquity 63:215224

Ward, W.T. 1977 Sand movement on Fraser Island: A response to changing climates. University of Queensland, Anthropology Museum, Occasional Papers in Anthropology 8:113-126.

Ward, W.T. and K.G. Grimes 1987 History of coastal dunes at Triangle Cliff, Fraser Island, Queensland. Australian Journal of Earth Sciences 34:325-333.

Ward, W.T. and K.G. Grimes 1988 Reply to discussion: History of coastal dunes at Triangle Cliff, Fraser Island, Queensland. Australian Journal of Earth Sciences 35:583-587.

Whitehouse, F.W. 1968 Fraser Island - geology and geomorphology. Queensland Naturalist 19(1-3):3-9.

Williams, F. 1982 Written in Sand: A History of Fraser Island. Brisbane: Jacaranda Press. 
Appendix A. Waddy Point 1 Rockshelter, Square A, Excavation Data and Dominant Materials. Note that weights of $0.1 \mathrm{~g}$ designate weights of $0.1 \mathrm{~g}$ or less.

\begin{tabular}{|c|c|c|c|c|c|c|c|c|c|c|}
\hline \multirow[t]{2}{*}{$\mathbf{X U}$} & \multirow{2}{*}{$\begin{array}{l}\text { Max. } \\
\text { Depth } \\
(\mathbf{m m})\end{array}$} & \multirow{2}{*}{$\begin{array}{c}\text { Mean } \\
\text { Thickness } \\
(\mathbf{m m})\end{array}$} & \multirow{2}{*}{$\begin{array}{c}\text { Weight } \\
\text { (kg) }\end{array}$} & \multirow{2}{*}{$\begin{array}{l}\text { Volume } \\
\text { (L) }\end{array}$} & \multirow{2}{*}{$\begin{array}{l}\text { Shell } \\
\text { (g) }\end{array}$} & \multirow{2}{*}{$\begin{array}{c}\text { Crab } \\
\text { (g) }\end{array}$} & \multirow{2}{*}{$\begin{array}{c}\text { Bone } \\
\text { (g) }\end{array}$} & \multirow{2}{*}{$\begin{array}{c}\text { Charcoal } \\
\text { (g) }\end{array}$} & \multicolumn{2}{|c|}{ Stone Artefacts } \\
\hline & & & & & & & & & $\mathbf{n}$ & (g) \\
\hline 1 & 25 & 18 & 5.4 & 7 & 154.2 & 0 & 4.6 & 11.6 & 0 & 0 \\
\hline 2 & 48 & 23 & 6.7 & 7 & 71.3 & 0 & 0.9 & 7.2 & 0 & 0 \\
\hline 3 & 88 & 26 & 6.1 & 7 & 59.2 & 0.3 & 0.8 & 3.2 & 0 & 0 \\
\hline 4 & 122 & 30 & 9.5 & 9.5 & 224.2 & 0.1 & 2.5 & 19.1 & 0 & 0 \\
\hline 5 & 164 & 36 & 8.1 & 8.5 & 161.4 & 0.1 & 5.4 & 40.1 & 0 & 0 \\
\hline 6 & 204 & 37 & 10.3 & 11 & 224.5 & 0.1 & 4.3 & 53.2 & 6 & 0.4 \\
\hline 7 & 236 & 30 & 8 & 8 & 104.1 & 0 & 1.9 & 49.2 & 5 & 2.2 \\
\hline 8 & 272 & 34 & 10.4 & 10.5 & 180.1 & 0 & 3.8 & 49.6 & 1 & 0.9 \\
\hline 9 & 272 & 18 & 6.1 & 6 & 255.8 & 0.1 & 1.7 & 28.6 & 1 & 0.1 \\
\hline 10 & 301 & 25 & 7 & 7 & 221.9 & 0.3 & 5.2 & 20.3 & 0 & 0 \\
\hline 11 & 338 & 24 & 8.5 & 9 & 511.1 & 0.5 & 11.2 & 35.4 & 0 & 0 \\
\hline 12 & 367 & 31 & 11.4 & 11 & 707.3 & 0 & 7.3 & 35.5 & 0 & 0 \\
\hline 13 & 384 & 23 & 7 & 7 & 328 & 0 & 2.5 & 12.8 & 0 & 0 \\
\hline 14 & 419 & 24 & 7.3 & 7.5 & 279.7 & 0 & 0.7 & 16.4 & 0 & 0 \\
\hline 15 & 455 & 45 & 16.7 & 17 & 823.1 & 0 & 3 & 19.9 & 1 & 0.1 \\
\hline 16 & 505 & 40 & 10.9 & 12.5 & 220.8 & 0.5 & 1.8 & 5.1 & 0 & 0 \\
\hline 17 & 539 & 36 & 11.3 & 12.5 & 138.1 & 0 & 4.1 & 3.7 & 0 & 0 \\
\hline 18 & 592 & 40 & 12.3 & 14 & 194.4 & 0 & 15.9 & 19.9 & 0 & 0 \\
\hline 19 & 661 & 63 & 21.5 & 24 & 524 & 0.1 & 17.8 & 52.8 & 0 & 0 \\
\hline 20 & 708 & 50 & 15.5 & 16.5 & 267.4 & 0 & 18.8 & 46.2 & 0 & 0 \\
\hline 21 & 767 & 75 & 22 & 22 & 1143 & 0.3 & 16.1 & 76.2 & 1 & 7.9 \\
\hline 22 & 818 & 47 & 16.7 & 16 & 976.2 & 0.1 & 11.7 & 93.1 & 2 & 1.8 \\
\hline 23 & 866 & 44 & 13.8 & 13 & 1436.6 & 0 & 4.2 & 57.4 & 0 & 0 \\
\hline 24 & 911 & 37 & 14 & 13 & 694.9 & 0 & 0.9 & 24.3 & 0 & 0 \\
\hline 25 & 949 & 38 & 13 & 12.5 & 203.5 & 0 & 0.3 & 7 & 3 & 1.9 \\
\hline 26 & 984 & 45 & 16.3 & 15.5 & 117.1 & 0 & 0.1 & 8.6 & 0 & 0 \\
\hline 27 & 1032 & 39 & 13.8 & 12.5 & 29 & 0 & 0.1 & 3.4 & 0 & 0 \\
\hline 28 & 1069 & 33 & 11.6 & 11.5 & 1.1 & 0 & 0 & 0.6 & 0 & 0 \\
\hline 29 & 1116 & 42 & 13.3 & 12.5 & 23.9 & 0 & 0 & 2.3 & 0 & 0 \\
\hline 30 & 1153 & 39 & 15.8 & 14.5 & 16.2 & 0 & 0 & 0.2 & 0 & 0 \\
\hline 31 & 1203 & 54 & 18.4 & 17 & 1.1 & 0 & 0 & 0.2 & 1 & 0.1 \\
\hline
\end{tabular}


Appendix A. Waddy Point 1 Rockshelter, Square A, Excavation Data and Dominant Materials. Note that weights of $0.1 \mathrm{~g}$ designate weights of $0.1 \mathrm{~g}$ or less (cont.).

\begin{tabular}{|c|c|c|c|c|c|c|c|c|c|c|}
\hline \multirow[t]{2}{*}{$\mathbf{X U}$} & \multirow{2}{*}{$\begin{array}{l}\text { Max. } \\
\text { Depth } \\
(\mathrm{mm})\end{array}$} & \multirow{2}{*}{$\begin{array}{c}\text { Mean } \\
\text { Thickness } \\
(\mathbf{m m})\end{array}$} & \multirow{2}{*}{$\begin{array}{c}\text { Weight } \\
\text { (kg) }\end{array}$} & \multirow{2}{*}{$\begin{array}{c}\text { Volume } \\
\text { (L) }\end{array}$} & \multirow{2}{*}{$\begin{array}{c}\text { Shell } \\
\text { (g) }\end{array}$} & \multirow{2}{*}{$\begin{array}{c}\text { Crab } \\
(\mathrm{g})\end{array}$} & \multirow{2}{*}{$\begin{array}{c}\text { Bone } \\
\text { (g) }\end{array}$} & \multirow{2}{*}{$\begin{array}{c}\text { Charcoal } \\
\text { (g) }\end{array}$} & \multicolumn{2}{|c|}{ Stone Artefacts } \\
\hline & & & & & & & & & $\mathbf{n}$ & (g) \\
\hline 32 & 1240 & 44 & 14.4 & 13 & 0.2 & 0 & 0 & 0.2 & 0 & 0 \\
\hline 33 & 1297 & 47 & 16 & 15 & 7.4 & 0 & 0.6 & 0.6 & 0 & 0 \\
\hline 34 & 1345 & 51 & 18.5 & 17 & 0 & 0 & 0.2 & 0.5 & 0 & 0 \\
\hline 35 & 1395 & 59 & 21 & 18 & 1.6 & 0 & 0 & 0.3 & 0 & 0 \\
\hline 36 & 1448 & 49 & 15.6 & 14 & 1.6 & 0 & 0 & 1 & 0 & 0 \\
\hline 37 & 1513 & 73 & 27.6 & 25 & 0 & 0 & 0 & 0.3 & 0 & 0 \\
\hline 38 & 1571 & 58 & 19.1 & 19 & 0 & 0 & 0 & 0.6 & 0 & 0 \\
\hline 39 & 1637 & 60 & 24.9 & 23.5 & 0.1 & 0 & 0.1 & 2.2 & 1 & 1.8 \\
\hline \multicolumn{2}{|c|}{ TOTAL } & - & 525.8 & 517 & 10304.1 & 2.5 & 148.5 & 808.8 & 22 & 17.2 \\
\hline
\end{tabular}

